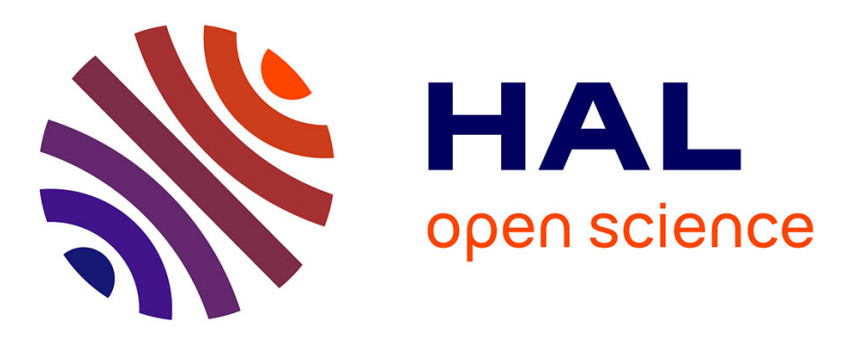

\title{
The junction of Fensch and Moselle rivers, France; mineralogy and composition of river materials
}

Emmanuelle Montargès-Pelletier, Laurent Jeanneau, Pierre Faure, Isabelle Bihannic, Odile Barres, Bruno Lartiges

\section{- To cite this version:}

Emmanuelle Montargès-Pelletier, Laurent Jeanneau, Pierre Faure, Isabelle Bihannic, Odile Barres, et al.. The junction of Fensch and Moselle rivers, France; mineralogy and composition of river materials. Environmental Geology, 2007, 53 (1), pp.85-102. 10.1007/s00254-006-0621-6 . hal-03176858

\section{HAL Id: hal-03176858 \\ https://hal.science/hal-03176858}

Submitted on 22 Mar 2021

HAL is a multi-disciplinary open access archive for the deposit and dissemination of scientific research documents, whether they are published or not. The documents may come from teaching and research institutions in France or abroad, or from public or private research centers.
L'archive ouverte pluridisciplinaire HAL, est destinée au dépôt et à la diffusion de documents scientifiques de niveau recherche, publiés ou non, émanant des établissements d'enseignement et de recherche français ou étrangers, des laboratoires publics ou privés. 


\title{
The junction of Fensch and Moselle rivers, France. Mineralogy and composition of river materials
}

\author{
Emmanuelle MONTARGES-PELLETIER ${ }^{1}$, Laurent JEANNEAU ${ }^{2}$, Pierre FAURE ${ }^{2}$, Isabelle \\ BIHANNIC ${ }^{1}$, Odile BARRES ${ }^{1}$, Bruno S. LARTIGES ${ }^{1}$ \\ ${ }^{1}$ Environment and Mineralurgy Laboratory, Nancy University, CNRS-INPL-ENSG, 15, \\ avenue de Charmois, BP 40, 54501 Vandoeuvre les Nancy Cedex, France. \\ Emmanuelle.montarges@ensg.inpl-nancy.fr \\ ${ }^{2}$ G2R, Nancy university, CNRS- Université Henry Poincaré - Nancy I, BP 239, 54506 \\ Vandoeuvre lès Nancy Cedex, France.
}

\begin{abstract}
The Moselle river flows in the north-east of France, from Vosges Mountains to neighboring countries Luxembourg and Germany. One of its tributaries, the Fensch River, drains a highly industrialized watershed, strongly impacted by mining, smelting and surfacing activities. The objective of this work, part of a general research program on Moselle watershed (Zone Atelier Moselle) was to assess the impact of the polluted Fensch river on the global quality of the Moselle river.

For that purpose, water, sediments and suspended particulate matter were sampled in both rivers, upstream and downstream the junction. Four main sampling campaigns were carried out, in winter during a flood event and in spring at low water level.

On a first step, mineralogical analyses (XRD and FTIR) and chemical analyses (ICP-MS, ICP-AES), were performed on sediments, suspended particulate matters and filtered waters. Major and trace elements concentrations were obtained on two different granulometric fractions $(0-2 \mathrm{~mm}$ and $0-50$ $\mu \mathrm{m})$ revealing the enrichment in heavy metals of fine particles. From one collecting campaign to another, seasonal variations could be evidenced on suspended matter composition even though major minerals (calcite, quartz and kaolinite) were always present. Furthermore, spatial variations were evidenced for Fensch and Moselle downstream sediments. Thus, very fine-grained sediments, poorly crystallized, displaying at the same time higher metal concentrations and higher organic matter content than in Fensch river material, were collected downstream, in a low hydrodynamic conditions zone,
\end{abstract}


assumed as a preferential sedimentary zone or even as a placer. Strong correlations could be revealed between iron content and contaminant concentrations, confirming the origin of polluted material. 


\section{Introduction}

Sediments and suspended matter are both known to play a key role in the adsorption, transport and deposition of elements in the environment. It is well established that metals and other contaminants (As, PAHs, organochlorines...) are intimately associated with fine-grained matter frequently transported as suspended matter, particulate or colloidal (Martin and Meybeck, 1979; McCarthy and Zachara, 1989; Douglas et al., 1993; Santiago et al., 1994; Batson et al., 1996; Van Metre and Mahler, 2004). The relation between suspended matter and bottom sediment has been investigated for different water bodies, unraveling a direct link between compositions of sediments and SPM. For instance, a study on Baltic Sea, (Strandberg et al., 1998), investigating organochlorine compounds content in sediments and suspended particle matter samples, suggested a parent-like link between colllected SPM and bottom sediment with however significant variations as contamination levels are not always identical between bottom and suspended sediments. A study of Adige river in Italy, revealed an increase of contaminants in SPM towards bottom sediments, and in particular for low solid charge conditions ((Douglas et al., 1993) and references therein). However, when performing sampling campaigns for two different years, Vignati et al. (Vignati et al., 2003), observed in one case (1994) no significant differences in trace element content between bed and mobilized sediments, but noticed an increase of $\mathrm{Cd}, \mathrm{Mn}, \mathrm{Pb}, \mathrm{Hg}$ and $\mathrm{Zn}$ in $\mathrm{SPM}$, for a second campaign (1996). The link between bed and suspended sediments is therefore hardly dependent on environmental (nature, frequency and amounts of releases in the riverine system) and hydrological conditions as hydrodynamic influence on the variation in concentration and chemical redistribution processes. It then appears that the link between the various compartments in natural aqueous systems can be convincingly interpreted, mainly in the case of small and simple water bodies (Van Metre et al., 1997; Van Metre and Mahler, 2004).

In the present study, we are interested in the confluence zone between the Fensch and Moselle rivers in the North-East of France. Such a site has attracted our attention due to the marked difference in water quality between both rivers. Indeed the Fensch River drains a heavily industrialised watershed, covering about $82.8 \mathrm{~km}^{2}$ and strongly affected, by mining, smelting 
and surfacing activities. In addition, due to the high population density in the vicinity, the river reach is modified and significant polluting inputs are generated through domestic sewage and drainage of urban surfaces. For these reasons Fensch river was even classified as the most polluted French river in the eighties. In contrast, Moselle displays a good quality level river and is used as the main source of drinking water in the North East of France. The Fensch-Moselle confluence zone then represents a very relevant situation to assess the impact of a polluted tributary on the global quality of the mainstream river and to address the issue of conservative or non-conservative behavior of elements in the mixing zone. Although numerous studies deal with estuaries where continental waters meet sea waters ((Aucour et al., 2003) and references therein), the confluence of two rivers was much less studied as such zones are expected to display less marked difference in water chemistry than what is commonly encountered in estuaries. However, in the case of rivers junction such as the confluence of Rio Negro and Rio Solimões (Aucour et al., 2003) or smaller streams in Colorado (McKnight et al., 1992) the analyses of dissolved and particulate fractions revealed the relative influence of oxides surfaces in the transport and fractionation of dissolved organic matter, and thus demonstrated the occurrence of sorption, reduction processes in the mixing zone.

This works tries to demonstrate how polluted material can be recovered downstream the confluence, in the different compartments of the Moselle river, i.e., water, SPM and sediments. For this purpose, a detailed chemical and mineralogical description of river materials was carried out, focusing mainly on metallic and metalloid contaminants (the study of organic contamination will be reported elsewhere (Jeanneau et al 2006, submitted)). In order to establish the possible links between bed and suspended sediments, water, sediments and suspended particulate matter were sampled in both rivers, upstream and downstream the junction. Four main sampling campaigns were carried out, in winter during a flood event and in spring at low water level. Additionnal samples of suspended particulate matter were collected to assess variability of flow conditions. Our objectives were mainly to describe the different compartments of both rivers before and after the confluence in order to follow pollution distribution and eventual modifications due to mobilization and re-settling. 


\section{Experimental section}

\section{Study area}

Figure 1 presents the geographic situation of the sampling area. Moselle river is the main tributary of Rhine river, and flows into it in Koblenz, Germany. The study area is located in the upstream zone of the Moselle basin, downstream the main cities of the region, Nancy and Metz, and after Meurthe river discharge, Meurthe being the major tributary of Moselle river (it represents about $20 \%$ of its water flow). At this location, the Moselle river has already received the saline inputs from Meurthe and Seille rivers, the domestic sewage inputs from Nancy and Metz, as well as the discharge of minor streams Rupt de Mad and Orne, the latter draining a mining and steel industry area.

The water flow of Moselle River is measured daily in Uckange, which is about $2 \mathrm{~km}$ upstream our study area (see hydrogramms on figure 2). In addition, water analysis is performed monthly, showing a conductivity relatively high $1522 \pm 354 \mu \mathrm{S} \mathrm{cm}^{-1}$, essentially due to chlorides $[\mathrm{Cl}]=352 \pm 91 \mathrm{mg} \cdot \mathrm{l}^{-1}$, sulfates $\left[\mathrm{SO}_{4}{ }^{2 \cdot}\right]=107 \pm 55 \mathrm{mg} \cdot \cdot^{1-1}$, hydrogenocarbonates $\left[\mathrm{HCO}_{3}\right]=146 \pm 31 \mathrm{mg} \cdot 1^{-1}$, calcium $\left[\mathrm{Ca}^{2+}\right]=162 \pm 33 \mathrm{mg} .1^{1^{-1}}$ and sodium $\left[\mathrm{Na}^{+}\right]=116 \pm 40 \mathrm{mg} \cdot 1^{-1}$. Suspended matter can vary from 2 milligrams per liter to 144, with an average value about 18 mg.1. other the period 1996-2005. $\mathrm{pH}$ is rather basic, $7.80 \pm 0.31$.

The Fensch river takes its source in Fontoy and receives three other streams : Petite Fensch, Marspich and Kribsbach. The hydrographic network is highly influenced by the permeable character of the substratum and the intense fracturing of subsoil due to mining. The river layouts of Fensch and Kribsbach have been modified (dotted lines on figure 1) as Fensch river was naturally discharging in Veymerange river and Kribsbach was a direct affluent of Moselle river. The Fensch water flow, $0.8 \mathrm{~m} / \mathrm{s}$ at lowest water level, is strongly increased by industrial and domestic rejects, from Knutange to Florange. These rejects are particulary meaningful in terms of flow $(0.55 \mathrm{~m} / \mathrm{s})$, of suspended particles $(520 \mathrm{~kg} / \mathrm{d})$, metals $(23.4 \mathrm{~kg} / \mathrm{d}$ iron mainly), phosphates $(30 \mathrm{~kg} / \mathrm{d})$ and hydrocarbons $(10 \mathrm{~kg} / \mathrm{d})$. The Fensch river is physically modified on the majority of its course, as the major river bed has almost disappeared under urbanisation and industrialisation. Most of the banks are artificial (concrete, rocks) in the first 
half. Also, one third of the river is recovered by industrial facilities, diminishing drastically the self-cleaning capacity of the river. The present morphology of Fensch river strongly reduces the usual functions of a river as floods are artificially retained. Furthermore, the last section of the Fensch river, meaning approximatively one kilometer before the Moselle river, is a stagnant reach, with a over-calibrated and uniform river bed, surrounded by imposing banks. This deeply embanked zone thus displays preferential sedimentary areas with formation of anoxic silty deposits, enriched in organic and metallic pollutants. Those silty sediments are easily remobilizable and constitute a particular hazard for the quality of Moselle river.

Fensch waters were analyzed before the last section, in Florange, downstream the wastewater plant. Although there was no flow measurement after 2001, an average value of water flow of $2 \mathrm{~m}^{3} . \mathrm{S}^{-1}$ can be retained. As Moselle river, Fensch river is relatively highly concentrated in salts, conductivity values surrounding $1401 \pm 315 \mu \mathrm{S} . \mathrm{cm}^{-1}$ on the same period. The salinity of water is mainly due to to hydrogenocarbonates $\left[\mathrm{HCO}_{3}\right]=281 \pm 38 \mathrm{mg} .1^{1-}$, sulfates $\left[\mathrm{SO}_{4}{ }^{2}\right]=$ $245 \pm 69 \mathrm{mg} \cdot \mathrm{l}^{-1}$, chlorides $[\mathrm{Cl}]=167 \pm 75 \mathrm{mg} \cdot \mathrm{l}^{-1}$, calcium $\left[\mathrm{Ca}^{2+}\right]=149 \pm 18 \mathrm{mg} \cdot \mathrm{l}^{-{ }^{-1}}$ and sodium $\left[\mathrm{Na}^{+}\right]=110 \pm 44 \mathrm{mg} \cdot \mathrm{l}^{-1}$. The higher concentrations in hydrogenocarbonates come from the fact that Fensch waters pass through carbonaceous formations of Mosellan plateau. The presence of sulfates reveals a contamination of surface waters by mines discharge. $\mathrm{pH}$ is rather basic, $7.93 \pm 0.2$, close to $\mathrm{pH}$ value of Moselle waters. The particle charge is however higher, as it transports between 3.6 and $262 \mathrm{mg} \cdot \mathrm{l}^{-1}$ of suspended matter $\left(26 \mathrm{mg} . \mathrm{l}^{\bullet}\right.$ being the average value on the 1996-2005 period) mainly due to the industrial and domestic inputs throughout the river course. One other characteristic of Fensch river is its temperature. Although the mean value $\left(15.4 \pm 3.5^{\circ} \mathrm{C}\right)$ is close to temperature of Moselle waters $\left(14.7 \pm 7^{\circ} \mathrm{C}\right)$, it never goes lower than $9^{\circ} \mathrm{C}$ or higher than $25^{\circ} \mathrm{C}$. This temperature regulation is also an effect of anthropogenic discharges in the river.

\section{Sampling}

Sediments were sampled in different locations around the junction of Moselle and Fensch rivers (figure 1) in flood and low-level conditions from January 2004 to July 2005 (figure 2, 
$540 \mathrm{~m}^{3} / \mathrm{s}$ and $36.6 \mathrm{~m} / \mathrm{s}$ are respectively the maximum and minimal values of Moselle water flows encountered during the sampling campaigns).

Materials from the Fensch river are refered to as «Fensch», and those from the Moselle are refered to as «Upstream » and « Downstream ». Sampling in the upstream areas (Moselle and Fensch) was performed in a zone of a $10 \mathrm{~m}$ diameter (figure 1) at four different times (January 2004, June 2004, February 2005 and June 2005). For the downstream area, sediments were sampled in one or two different locations for each campaign, in order to unravel the heterogeneity of sedimentary deposits. Indeed, the downstream area displays specific features, as the river bed profile is rather heterogeneous in the hundred meters following the junction. In particular, on the left side, one can observe a surelevated island, covered by waters upon flooding and emerged when the Moselle level is low. In low level or low flow conditions, the water trapped between the island and the left bank, does not join the Moselle which then strongly enhances settling of suspended materials as sedimentation conditions are then close to those encountered in lakes. Figure 1 locates the six different sampling spots in the downstream area, the subsequent samples being refered as to Downstream-a, -b, -c, -d, -e, and -f.

The different procedures of water, sediments and SPM sampling are summarized in figure 3. Sediments were collected as 45-60 cm cores, using a Beeker sampler (Eijkelkamp), equipped with polyethylene sampling tubes. For the two first campaigns in 2004, the sediment cores were divided in three of four sections of $15 \mathrm{~cm}$ each. For the latter campaigns, the cores were kept as one sample. The different sediments were freeze-dried and sieved at $2 \mathrm{~mm}, 250 \mu \mathrm{m}$ and $50 \mu \mathrm{m}$. The different analysis were performed mainly on the coarse fraction 0-2 $\mathrm{mm}$ and the fine fraction 0-50 $\mu \mathrm{m}$. Surficial sediments of Fensch were collected employing sedimenttrap, settled in the bottom of the river during one week (November 2004).

Water was sampled in four different places corresponding to «Upstream», «Fensch», «Downstream-c» and «Downstream-f». Conductivity and $\mathrm{pH}$ values were measured on site, with electrodes dedicated to field-measurements. For every station, an aliquot of $100 \mathrm{ml}$ was 
immediately filtered at $0.22 \mu \mathrm{m}$ on cellulose syringe-filters and subsequently acidified with $\mathrm{HNO}_{3} 1 \mathrm{~N}$ before chemical analyses.

Suspended matter was retrieved after centrifugation of 20 liters of raw water and freezedrying. Furthermore, thanks to a collaboration with the Regional water Agency (Agence de bassin Rhin-Meuse), seven samples of suspended solids were collected monthly in the Fensch river from January to August 2003 (see sampling days on figure 2).

\section{Analytical methods}

Chemical analyses were perfomed on coarse and fine fractions of sediments, on SPM when the collected amount was sufficient, and on filtered water. For solid samples, an aliquot of $200 \mathrm{mg}$ was smelt with $600 \mathrm{mg} \mathrm{LiBO}_{3}$ in Pt-Au crucibles, and then dissolved using $\mathrm{HNO}_{3}$ $(1 \mathrm{~N})$. The resulting solution was then analyzed by ICP-AES (major and minor elements) and by ICP-MS (trace elements). Filtered water samples were analyzed in the same way.

$\mathrm{X}$-ray diffraction data were obtained using a D8 Bruker diffractometer with Co $\mathrm{K}_{a 1}$ radiation $(\lambda=1.7902 \AA)$. The diffractomer is equipped with a $(\theta, 2 \theta)$ goniometer and a position sensitive detector (PSD). X-ray diffractogramms were collected on powder samples (sediments and SPM) in ambient conditions, within the $2 \Theta$ range $\left[3,65^{\circ}\right]$, with $0,036^{\circ}$ step and $3 \mathrm{~s}$ collecting time.

Fourier-Transform Infrared spectra were obtained in transmission mode using a Bruker IFS 55 Fourier IR spectrometer at a resolution of $4 \mathrm{~cm}^{-1}$. For that purpose, pellets were made by mixing $1 \mathrm{mg}$ of sample with $70 \mathrm{mg}$ of pure $\mathrm{KBr}$. For a few selected samples, additional diffuse reflectance IR spectra were collected. In that case $7 \mathrm{mg}$ of sample were mixed with 70 mg of pure $\mathrm{KBr}$.

\section{Results}

1.Water, dissolved fraction

Table 1 presents major and trace elements concentrations for four different sampling campaigns. In the downstream area, we distinguished waters sampled in the region of Downstream-c from water samples collected further from the confluence, in downstream-e 
area (see figure 1). Water analysis revealed the presence of major cations $\mathrm{Ca}^{2+}, \mathrm{Na}^{+}, \mathrm{Mg}^{2+}$, and $\mathrm{K}^{+}$, whom concentrations added to counter-ions carbonates, sulfates and chlorides, induce a relatively high conductivity $\left(1350-1700 \mu \mathrm{S} . \mathrm{cm}^{-1}\right)$. In agreement with measurements reported by Water data Bank of Basin Agency, Fensch and Moselle water samples display similar contents in major cations and anions. Downstream the confluence, Moselle waters exhibit intermediate concentrations between Upstream and Fensch waters. Fensch water is slightly more concentrated in potassium, magnesium and silicium and Moselle water is slightly more concentrated in calcium.

It then appears that the mixing of Fensch and Moselle rivers should not yield such physicochemical variations compared to those occuring in estuaries when continental waters encounter marine fluids. In addition, $\mathrm{pH}$ values of both rivers are rather close. In contrast, significant variations are observed regarding water temperature, dissolved organic carbon content and solid charge. The former may induce redox reactions in the mixing zone, whereas suspended particulate should enhance sorption processes.

The four campaigns reported in this table represented four different physical and chemical conditions. For the first campaign, in january 2004, the flow for both rivers was high (see table 1 and figure 2), and waters had a relatively high load in suspended particulate.

For major elements, waters sampled after the confluence (downstream-c) display intermediate concentrations between Fensch and Moselle concentrations, excepted for Ca in January 2004 and Mg in June 2005.

Some discrepancies appear for trace element concentrations. Fensch river presents higher concentrations in $\mathrm{Zn}$ and $\mathrm{Mn}$, whereas Moselle river displays higher contents in $\mathrm{Cr}$. Trace elements concentrations are in all cases higher than those given as natural level (Meybeck et al., 1996; Vignati et al., 2003). None of the water samples presents higher metal concentrations than those recommended for raw surface waters in the purpose of drinkable water production.

The contribution factor $f$ of Fensch waters after the rivers junction can be calculated according to the following formula : 
$f=\left(\mathrm{C}_{\mathrm{v}}-\mathrm{C}_{\mathrm{D}}\right) /\left(\mathrm{C}_{\mathrm{v}}-\mathrm{C}_{\mathrm{F}}\right)$, with $\mathrm{C}_{\mathrm{v}}$ the concentration of one element in Moselle waters upstream the confluence, $C_{D}$ for downstream waters and $C_{F}$ in Fensch waters. $f_{c}$ is the contribution factor in sampling point downstram-c, and $\mathrm{f}_{\mathrm{f}}$ is the contribution factor in the lowermost sampling point, downstream-f. These factors are reported on table 1 for the four series of water samples. The higher $\mathrm{f}$, the higher the contribution of Fensch river to the chemistry of Moselle water after the confluence. These factors are strongly dependent of physico-chemical processes occurring upon water mixing such as ion exchange, sorption, desorption, which explains the nonconservative character of elements concentrations. Although the calculated values display large variations from one element to another or even from one series to another, they are indicative of Fensch contribution and evolve logically with hydrodynamical conditions as they decrease with distance from the mixing zone. They also depend strongly on flow conditions. For instance, silicium concentrations are more influenced by Fensch waters in the case of low or mean charge (February, June and July 2005) than in the case of flood conditions as in January 2004.

\section{Major components, mineralogy of river solid materials,}

a/ Moselle river before the junction : «Upstream »

The results obtained for the different granulometric fractions and the different sampling campaigns were too numerous to be presented in an exhaustive way. Thus, chemical analyses data will be summarized using the mean values obtained for sediments from each sampling locations. Table 1 presents the average values of $\mathrm{SiO}_{2}, \mathrm{Al}_{2} \mathrm{O}_{3}, \mathrm{Fe}_{2} \mathrm{O}_{3}, \mathrm{MgO}, \mathrm{CaO}$, and organic carbon content obtained for the entire core of upstream sediments, for four different samplings (9 different samples). First sampling was performed in January 2004, during a flooding period (see figure 2) and core sample was collected near the river bank as it was impossible to collect samples in the river bed during high flows. The other core samples were collected in June 2004, February and June 2005. During those periods, the water level was low (Moselle hydrogramms on figure 2), which allowed us to sample in preferential sedimentation zones of the river bed. For upstream sediments, the composition in major inorganic elements remains relatively constant with depth and location whereas organic matter proportion displays marginal changes around 2-3\%. Those sediments are rather 
siliceous with $\mathrm{SiO}_{2}$ content of $54 \pm 4 \%$ and with a ratio $\left(\mathrm{SiO}_{2}+\mathrm{Al}_{2} \mathrm{O}_{3}\right) / \mathrm{Fe}_{2} \mathrm{O}_{3}$ going from 7.6 to 11.0. The fine fractions (0-50 microns) show a slight enrichment in aluminum and iron for all the samples, which agrees with the high contents in phyllo-aluminosilicates and iron-bearing phases in silty samples. The comparison with Upper Continental Crust composition (Table 1 (Wedepohl, 1995)) shows that Upstream sediments are slightly poorer in silica, alumina and magnesium oxide while the influence of carbonaceous geological background induces a slightly higher content in $\mathrm{CaO}$.

XRD and FTIR data presented on Figure 4 were selected as typical diffractogramm and spectra of the 18 sediment samples analyzed for the Upstream zone. XRD (Figure 4a) revealed the presence of major crystalline phases related to primary minerals such as quartz and feldspars (Albite, K-feldspars), and also detritic minerals such as carbonates, mainly calcite and dolomite, and phyllosilicates (illites, micas, chlorites, vermiculites and kaolinite). There was no noticeable modification of the mineralogy with depth, granulometric fraction or sampling place, at least at the macroscopic scale. FTIR spectra on figure $4 \mathrm{~b}$ demonstrated slight variations of carbonates content (calcite mainly) evidenced by the variations of $-\mathrm{CO}_{3}^{2}$ vibration bands centered at 1429, 876 and $716 \mathrm{~cm}^{-1}$. In a similar way, kaolinite signal (3697, $3612 \mathrm{~cm}^{-1}$ ) varies and increases with depth. The collected spectra also demonstrated the presence of organic matter through the vibration bands of alkyl groups $-\mathrm{CH}_{3},-\mathrm{CH}_{2}$ in the $3000-2000 \mathrm{~cm}^{-1}$ range.

b/Fensch river

Sediments from Fensch river present a very different general aspect, in terms of color, smell and texture. The Fensch river bed was strongly modified. From its source in Fontoy to the junction with Moselle river, the Fensch river displays several covered portions, unfavourable to a correct areation of the aquatic medium, and the major part of the river bed is reduced in width. In the last section of the stream, where sampling was performed, the river bed is not only narrowed but artificially hemmed by steep banks, which enhances material accumulation and the presence of silting zones. The sediments collected in settling zones were dark and 
fine, with an apparent charge in hydrocarbons, as their sampling induced the release of immiscible hydrocarbons remaining at the surface level of waters. These zones are in the vicinity of the banks, where hydrodynamic conditions are known to be weaker than in the main axis of the river. The other zones display sandy sediments recovered by a more or less thin layer of silty and black material, the thickness varying from 5 to $15 \mathrm{~cm}$. Four sediments cores were withdrawn in different places, each point being distant from 1 to 3 meters. The first two cores (january and june 2004), were divided into three parts, about $15 \mathrm{~cm}$ long. The composition in major elements is strongly different from upstream materials (table 2), revealing the main influence of iron-related activities in this river basin (iron mine waters and steel industry outflows). The results of chemical analyses also reveal strong variations with sampling location, depth and granulometry, that were not encountered for the sediments collected in the upstream zone. The iron and calcium contents $\left(\mathrm{Fe}_{2} \mathrm{O}_{3}\right.$ and $\left.\mathrm{CaO}\right)$ are particularly high, $\mathrm{Fe}_{2} \mathrm{O}_{3}$ contents going from 14.5 to $46.5 \%$ in coarse fractions, from 17 to $65 \%$ in fine fractions. Sediment core sampled in January 2004 presents even higher contents in $\mathrm{Fe}_{2} \mathrm{O}_{3}$ and $\mathrm{CaO}, \mathrm{SiO}_{2}$ content being limited to $20 \%$ only. This core displays a relatively siliceous top part, containing about $30 \%$ of $\mathrm{SiO}_{2}$. However, the inferior parts of the same core (medium and bottom) display lower $\mathrm{SiO}_{2}$ contents (13.9 and $13.6 \%$ respectively), replaced essentially by iron-bearing minerals, $\mathrm{Fe}_{2} \mathrm{O}_{3}$ reaching 46.5 and $45.2 \%$ respectively. The elemental ratio $\left(\mathrm{SiO}_{2}+\mathrm{Al}_{2} \mathrm{O}_{3}\right) / \mathrm{Fe}_{2} \mathrm{O}_{3}$ calculated for the coarse fractions goes from 0.6 to 3.2 , with a mean value at 1.54 to be compared with the value of 10.4 determined for upstream sediments. The composition patterns of fine fractions globally follow those of coarse samples. In details, $\mathrm{SiO}_{2}$ content, essentially due to the presence of quartz, always decreases from coarse to fine fraction. $\mathrm{CaO}$, which essentially represent calcium carbonates, tends to follow $\mathrm{SiO}_{2}$ behavior, but with a weaker magnitude. In an opposite way, $\mathrm{Fe}_{2} \mathrm{O}_{3}$ content increases in the fine fraction, reaching $65 \%$ in the fine fractions of the bottom section. In all cores, $\mathrm{Al}_{2} \mathrm{O}_{3}$ 
content, which can generally be related to the proportion of phyllosilicates, is rather constant $(4.8 \pm 1.2$ in coarse fraction ; $5.2 \pm 1.9$ in fine fraction) revealing close contents in clay materials for sediment samples. However, the $\mathrm{Al}_{2} \mathrm{O}_{3}$ contents in coarse fractions tends to follow $\mathrm{SiO}_{2}$ content as the highest values were encountered for the most siliceous samples. Comparing fine and coarse fractions, $\mathrm{Al}_{2} \mathrm{O}_{3}$ increase in fine fraction, traducing an enrichment in clay materials. FTIR spectra collected from Fensch sediments (figure 5a) reveal relatively high amount of organic matter, traduced by the intensities of alkyl $-\mathrm{CH}$ stretching vibrations (2850-2970 $\mathrm{cm}^{-1}$, kaolinite vibration bands at 3697 and $3626 \mathrm{~cm}^{-1}$ and carbonate signals centered at 1426,874 and $716 \mathrm{~cm}^{-1}$ these latter signals being characteristic of calcite.

XRD measurements (figure 5b) revealed the presence of several iron oxides : magnetite $\mathrm{Fe}_{3} \mathrm{O}_{4}$, wuestite $\mathrm{Fe} 0$ and hematite $\mathrm{Fe}_{2} \mathrm{O}_{3}$, iron phosphates (vivianite $\mathrm{Fe}_{3}\left(\mathrm{PO}_{4}\right)_{2} .8 \mathrm{H}_{2} \mathrm{O}$, wicksite $\left.\mathrm{NaCa}_{2} \mathrm{Fe}_{5} \mathrm{Mg}\left(\mathrm{PO}_{4}\right)_{6} .2 \mathrm{H}_{2} \mathrm{O}\right)$ and iron carbonates (siderite $\mathrm{FeCO}_{3}$, ankerite $\left.\mathrm{Ca}(\mathrm{Fe}, \mathrm{Mg}, \mathrm{Mn})\left(\mathrm{CO}_{3}\right)_{2}\right)$, oxides being dominant. Magnetite and wuestite lines increase in intensity with depth, which confirms that iron oxides are the main phases in the bottom sections of the sediment core. Carbonates contents vary from one sample to another, the major carbonate mineral being calcite as deduced mainly from FTIR spectra (figure 5a).

c/ Downstream samples.

The composition of the sediments zone following the confluence also reveals a strong hetreogeneity, but at a different scale as the investigated zone runs over more than $100 \mathrm{~m}$. This heterogeneity is mainly due to the variations of hydrodynamic conditions along the river and of course to the fact that Fensch river drawns into Moselle on the left bank, yielding differences of sediment and water quality from one margin to the other.

Table 2 presents the contents in few major elements ( $\mathrm{Si}, \mathrm{Al}, \mathrm{Fe}, \mathrm{Mg}$ and $\mathrm{Ca}$ ) of Downstream sediments for coarse and fine fractions of 6 different places (from $-\mathrm{a}$ to $-\mathrm{f}$, see figure 1). First sampling (Downstream-a in january 2004, see figure 1) was performed on the left bank, using the coring sampler. The resulting sediments present a composition close to Upstream 
sediments. Their $\mathrm{SiO}_{2}$ content is relatively constant with depth, $48 \pm 0.6 \%$. In comparison with Upstream sediments, there is a slight enrichment in iron as $\mathrm{Fe}_{2} \mathrm{O}_{3}$ increases from 6.2 to 8.8 $\%$. From a mineralogical point of view, the major minerals are primary and detritic minerals encountered for Moselle sediments, i.e., quartz, felsdpars, calcite, micas, kaolinite, and chlorite (figures 4 and 6). These downstream-a sediments appeared to evolve in a similar way than upstream sediments with composition rather stable with depth and $\mathrm{Fe}_{2} \mathrm{O}_{3}$ and $\mathrm{Al}_{2} \mathrm{O}_{3}$ contents increasing slightly from coarse to fine fraction.

Downstream-b sediments, sampled on the island (figure 1) are drastically different. Their general aspect is reminiscent to that of Fensch sediments, i.e., finely textured black sediments, with noticeable high hydrocarbons content. Moreover, these sediments, collected with the corer, displayed a clear stratification, with clear and dark lines, sandy and silty respectively, rich in calcite and quartz for clear layers, rich in organic matter and iron for dark layers. These downstream-b sediments displayed higher iron contents $\left(38.77 \pm 2.75 \% \mathrm{Fe}_{2} \mathrm{O}_{3}\right)$ and higher organic matter contents $(7.5 \pm 1.4 \%$ Organic Carbon) than Fensch sediments. Due to the high content in organic matter that acts as glue between particles, the fractionation between coarse and fine size fractions is difficult to achieve, coarse grains being mainly aggregates of smaller particles, embedded in organic matter. The presence of organic matter on the external surface of such aggregates could be evidenced by collecting FTIR spectra in diffuse reflectance mode that is more sensitive to surface species than transmission mode. Figure 6 compares the spectra obtained in transmission and diffuse reflectance modes. Besides kaolinite and carbonate both spectra exhibit intense $-\mathrm{CH}_{2}$ and $-\mathrm{CH}_{3}$ streching vibration bands in the range $3000-2850 \mathrm{~cm}^{-1}$, confirming the high organic content. Furthermore those bands are more intense in diffuse reflectance thus showing the presence of organic matter on the external surface of sediment grains.

Downstream-b sediments correspond to very particular hydrodynamic conditions that enhance the accumulation and settling of materials coming from the Fensch river. This is confirmed by the relative high content in iron (see table 2) coupled with a drastic diminution of silica. Actually, among all the samples studied, downstream-b sediments display the lowest $\mathrm{SiO}_{2}$ 
content. The depletion in silicate minerals can also be observed on XRD pattern (figure 7) as diffraction lines of quartz are hardly detectable beside diffraction lines of several iron oxides (magnetite, wuestite), or iron phosphates such as vivianite. Calcite is predominant in these sediments as revealed by XRD and FTIR. Other carbonates (dolomite, ankerite, magnesite) could also be identified.

Downstream-c sediments were collected in february 2005 using the core sampler, just a few meters beside Downstream-b sediments, but on the opposite edge of the island. Coring was difficult to perform and only $15 \mathrm{~cm}$ could be extracted. The resulting core was made of hardened argillaceous material as evidenced by their content in $\mathrm{Al}_{2} \mathrm{O}_{3}$ (up to $18.64 \%$ ), FTIR spectra (figure 8, c) and XRD patterns in random mode (figure 7) and for oriented preparations (not shown). The main diffraction lines appear around 14, 10, $7.3 \AA$ as $\mathrm{d}(001)$ lines, and $3.5 \AA$ revealing the presence of chlorite, illite and kaolinite. Oriented samples were additionally treated at room temperature with ethylene glycol. The absence of changes in the XRD patterns then reveals the absence of swelling clay minerals in the sample.

Downstream-d sediments, collected about thirty meters downstream, are comparable to downstream-a sediments, their composition is quite close to these of Moselle sediments before the confluence.

Downstream-e sediments were collected at the furthest distance from the confluence, on the left margin of the Moselle river. Still, they display clear «Fensch » features, as they appear relatively poor in silica and rich in iron-bearing phases as evidenced by XRD patterns that display magnetite and wuestite diffraction lines (figure 7,e).

Downstream-f samples were collected in July 2005. They appeared as the most siliceous ones, with $58.9 \% \mathrm{SiO}_{2}$ in the coarse fraction. This relatively high content in $\mathrm{SiO}_{2}$ is associated with a low content in iron oxides and a high content in $\mathrm{CaO}(13,84 \%$, table 2 , figure 7$)$. However 
the fine fraction of these sediments also suggests the presence of materials originating from the Fensch river, as the $\mathrm{Fe}_{2} \mathrm{O}_{3}$ content reached $16.75 \%$.

These different samples can be classified in three groups. The samples from a, d, e, and $\mathrm{f}$ represent a mixture of Moselle and Fensch materials with varying contribution of both sources. The sample b must be considered as a result of enhanced sedimentation and the last sample, Downstream-c can be considered as an extract of the river bed.

d) $S P M$

As far as suspended particulate matters are concerned, two cases must be distinguished, i.e. normal flow conditions and flood conditions. In the first case, the amount of suspended particulate matter collected Upstream was generally insufficient to perform chemical analyses for which significant quantities of material are required.

Table 1 presents the results of chemical analyses performed on freeze-dried suspended matter from the Moselle and Fensch rivers. Only one sample was analyzed from the Upstream station, four from the downstream-b station, two from the downstream-f station and twelve from the Fensch stations. The compositions in major elements of SPM samples from Moselle river both upstream and downstream are rather similar. The contribution of Fensch SPM only appears to induce a slight decrease of aluminium and silicon oxides and a slight increase in calcium and organic matter content. Figure 9 presents the composition variability observed for suspended material collected in the Fensch river from January 2003 to July 2005. A high variability is observed with $\mathrm{SiO}_{2}$ content varying from 7.7 to $31.6 \%$ and apparently positively correlated with $\mathrm{Al}_{2} \mathrm{O}_{3}$ and $\mathrm{Fe}_{2} \mathrm{O}_{3}$, non correlated with $\mathrm{CaO}$ content and negatively correlated with $\mathrm{MgO}$ and organic carbon content. The latter parameter varies from 3.3 to $12 \%$, reaching a maximum for samples collected in February 2003. On the basis of Moselle hydrogramms (figure 2), no direct link could be established between SPM composition and river flow, the major constituents, $\mathrm{SiO}_{2}, \mathrm{Ca} 0, \mathrm{Fe}_{2} \mathrm{O}_{3}$, do not follow the flow evolution and are apparently more affected by the nature and amount of anthropogenic inputs. 
The XRD and FTIR analyses of SPM are not always truly informative, especially in low flow conditions where the main materials are poorly crystallized phases. In such cases, the diffractograms and IR spectra are dominated by signals due to various salts such as $\mathrm{NaCl}$, $\mathrm{CaSO}_{4} \cdot \mathrm{nH}_{2} \mathrm{O}$, or hydrogenocarbonates, such as hydromagnesite resulting from the relatively high concentrations in calcium, sodium, chloride and carbonates, and also from the sample preparation procedure (settling, centrifugation and freeze-drying). During flood events, the amount of collected SPM is much more important. The XRD patterns obtained for SPM collected in January 2004, during a flood event (Figure 10) show that in such conditions, the mineralogy of the SPM is close to that of sediments for both Moselle and Fensch (except for the presence of a few salts resulting from the preparation procedure). Such a finding strongly suggests a remobilization of sedimented materials.

Although Fensch river transports ironbearing minerals, the iron concentration in the dissolved fraction is always below the detection limit $\left(0.02 \mathrm{mg} .1^{1}\right)$. Iron is known to precipitate in the range of $\mathrm{pH}$ values that Fensch river displays. Moreover, the presence of relatively high concentrations of calcium cations and phosphate anions suggest the in situ formation of pure or mixed phosphates precipitates such as vivianite or anapaite (see also XRD patterns on figure 7).

\section{Metallic pollution of river solid materials}

Trace elements concentrations for the various compartments are reported in Table 3.

Upstream sediments. The metal contents in Upstream sediments are higher than those reported for the mean composition of Earth's Crust (Wedepohl, 1995; Sprenke et al., 2000). Santiago et al. (Santiago et al., 1994) reported metal contents in sediments (As, Cd, Cr, Cu, $\mathrm{Hg}, \mathrm{Ni}, \mathrm{Pb}, \mathrm{Zn}$ ) from Rhone river, these values were in the same range of those collected for Moselle sediments except for $\mathrm{Pb}$ and $\mathrm{Zn}$ that appeared more concentrated in Moselle 
sediments. In comparison with values reported for other French rivers (Carpentier et al., 2002), the level of metallic pollution of the Moselle river in the area of Uckange can be classified as low to medium. In terms of sediment quality, trace elements contents can be compared to the guideline values effects-range-low (ERL) and effects-range-median (ERM), developed by the National Oceanic and Atmospheric Administration (NOAA) in the US (Long et al., 1995; McCready et al., 2006). ERL and ERM values are defined as the 10th and 50th percentiles of adverse biological effects. It must be pointed out that such indexes do not take into account the bioavailability of contaminants and the local parameters that could influence their chemical status. A rough estimate of sediments contamination can also be provided by the Alert and Intervention values (reported in Table 3) derived from a Dutch decree (circular on target values and intervention values for soil remediation, Ministry of Housing, Spatial Planning and Environment, upadted on 04/02/2002 (Carpentier et al., 2002)). It appears that upstream sediments present concentrations above ERL and below ERM, except for zinc whose concentration is higher than ERM. When considering alert recommandations, upstream sediments are higher than the A values for at least three elements : $\mathrm{Cr}, \mathrm{Pb}$ and $\mathrm{Zn}$.. For other elements $\mathrm{As}, \mathrm{Cu}$ and $\mathrm{Ni}$, the measured concentrations are very close to the $\mathrm{A}$ values. Upstream sediments can then be considered as moderately contaminated sediments.

Metals contents in upstream sediments can be compared with sediments analyses performed for 8 years (1996-2003) by the Regional Water Agency (AERM) in the survey station of Uckange on Moselle river, which is located about 2 kilometers upstream the confluence. For all trace elements reported but chromium, the concentrations found in cored sediments remain in the range described by Uckange materials, showing a relative constancy of contaminants presence in sediments over a 8 year period. However, Chromium content is more than twice that found in Uckange sediments. 
Along the cores of Upstream sediments, Arsenic, Chromium, Copper, Nickel and Tin remain rather constant, for coarse fractions as well as for fine fractions. Concentrations are slightly increased in fine fraction, which could indicate that these elements are associated to micronic mineral phases, with high surface area and specific adsorption sites (Warren and Zimmermann, 1994; Stumm and Morgan, 1995). In contrast, Lead and Zinc exhibit significant variations from one core section to another, with a general tendency of increasing with depth. This increase in lead and zinc is not related to a mineralogical modification as major elements and mineralogical phases were shown to remain constant from top to bottom, and are not related either to changes in sediments size distribution, which are identical in all core sections (Harland et al., 2000). Furthermore the concentrations in $\mathrm{Pb}$ and $\mathrm{Zn}$ increase in both fine and coarse fractions. In the second core (june 2004), variations in lead and zinc are less pronounced with lower average concentrations, closer to the reported values for Uckange sediments.

\section{Fensch materials.}

Fensch river sediments are much more polluted as reported concentrations are higher from those measured in Upstream sediments (Table 3). When compared with the concentrations reported by Regional Water Agency (AERM), for sediments collected once a year in Florange, $500 \mathrm{~m}$ upstream from our sampling area, the cored sediments appeared far more contaminated. Such a discrepancy may result from the fact that we collected deeper sediments. Indeed, along the core of Fensch sediments, there is a remarkable increase of concentrations in lead, zinc, chromium, tin, arsenic, copper and nickel, which is directly related to an increase of iron oxide minerals. In comparison with previous studies on river sediments, the pollution level of Fensch materials is comparable to those of rivers or lakes draining or receiving mine waters (Müller et al., 2000; Galan et al., 2003; Lacal et al., 2003; Audry et al., 2004; Morillo et al., 2004). Zn concentrations are comparable to those reported for other contaminated European rivers, such as Odiel river (Morillo et al., 2004), Tinto river (Galan et al., 2003), or Guadiamar river (Lacal et al., 2003) in Spain, or Deûle (Vdovic et al., 2006) in the North of France. The general level of metal contamination can be assessed on the basis of the limits provided by the Dutch decree (Carpentier et al., 2002). In the case of 
Fensch sediments, the values lie between alert A and intervention I for most metals whereas the zinc content $\left(2765 \mathrm{mg} . \mathrm{kg}^{-1}\right)$ is far above the intervention value of $720 \mathrm{mg} . \mathrm{kg}^{-1}$. Various origins can be proposed for zinc. Significant emissions of $\mathrm{Pb}$ and $\mathrm{Zn}$ are due to coal fly ash, the quantity of $\mathrm{Zn}$ being nearly double that of $\mathrm{Pb}$ and fossile fuel combustion is the main contributor to worldwide anthropogenic emissions of Zn (Callender and Rice, 2000). In addition $\mathrm{Zn}$ is also used in most commercial metal products (galvanized metal), is added during the manufacture of automobile tires in the form of $\mathrm{ZnO}$ as an accelerator in the vulcanization process and is a common contaminant of agricultural and food wastes. In the case of the Fensch river, it may be proposed that steel surfacing is the main reason for high $\mathrm{Zn}$ content, although additional analyses about $\mathrm{Zn}$ speciation have to be performed before giving a more detailed answer about $\mathrm{Zn}$ origin.

Suspended matter from Fensch river displays similar distributions in metallic contaminants (Table 3) with average values close to those observed for the fine fraction $(0-50 \mu \mathrm{m})$ of sediments. These relatively high contents in metals show that heavy metal transport takes place in particulate form. There is then a direct link between suspended matter and sediments, which can be interpreted as resulting from contaminant mobilization upon sediment remobilization.

In order to observe variability of concentration in time, Figure 11 displays trace elements concentrations in twelve different samples of SPM from Fensch river. Zn appears as the most concentrated for most samples, except for the material collected in february 2003. In that latter sample, Sn reaches almost $2500 \mathrm{ppm}$ and no clear interpretation about the origin of tin can be proposed. At the moment, from the comparison of figures, one can observe that the high concentration in tin is related with high concentrations in organic carbon and phosphorus (figure 9), suggesting a dysfunctioning of the WWT at that particular time. In any case, a high variability of contaminant content is observed in SPM, which reveals not only the importance of flow conditions, but also the irregular character of pollutant inputs (wastewater treatment 
and industrial inputs). As previously observed (Van Metre and Mahler, 2004), the variability in suspended matter composition is higher than that observed on sediments. This can certainly be related to the different time windows corresponding to these two types of materials.

Downstream sediments. In downstream samples, the heterogeneity revealed previously by mineralogical and chemical analyses of major elements contents, can also be observed for trace elements contents (Table 3).

Sediments collected in June 2004 in the low hydrodynamic zone (spot b on figure 1) constitute very singular samples as they display a higher level of metallic contamination than all other sediments collected in the junction zone, Fensch materials included. These sediments diplay a contamination above the intervention value set by the Ducth decree. Their presence, at aout $100 \mathrm{~m}$ after the confluence reinforces the idea that pollution stays in the vicinity of the source as it was already demonstrated for Seine river (Carpentier et al., 2002). Besides those dark, fine and highly polluted accumulations, the other samples of downstream sediments reveal a variation in their contamination level, which does not follow the distance from the confluence and is not the same for all elements. Indeed, for $\mathrm{Zn}$, the concentrations evolution is the following $[Z n]$ Ds-b $>[Z n] D s-e>[Z n] D s-a>[Z n] D s-f>[Z n] D s-d>[Z n] D s-c$. The same sequence is observed for $\mathrm{Cr}$ and As suggesting that those three elements have a similar path of mobilization-deposition. Copper and Tin seem to be linked by the sequence [Sn]Ds$b>[$ Sn $]$ Ds-e $>[$ Sn $]$ Ds-d $>[$ Sn $]$ Ds-a $>[$ Sn $]$ Ds- $f>[$ Sn]Ds-c. However, among the six different sampling points, $\mathrm{b}$ and e appear as the more contaminated. These two sampling zones are close to the river bank and correspond, above all in the case of downstream-b, to preferential settling conditions.

In Fensch and Downstream samples, the contamination of sediments and SPM is strongly 
linked to their content in iron minerals. On figure 12, we plotted trace elements contents versus $\mathrm{Fe}_{2} \mathrm{O}_{3}$ percentages in sediments and SPM samples. The left plots ( $\mathrm{F} 1$ to F4) concern Fensch samples, the right plots (D1 to D4) concern Downstream samples. For Fensch samples, $\mathrm{Zn}, \mathrm{Cr}$ and $\mathrm{Pb}$ contents in sediments are strongly correlated to iron content $(\mathrm{r}=0.88$; $0.91 ; 0.93)$ suggesting a similar source of contamination for these four elements, and similar distribution within the sediment core and between size fractions. For chromium and lead, it can be noticed that SPM and sediments show similar evolution with iron content, suggesting a common source for these elements, or by further extrapolation, it can be supposed that iron minerals are the main carriers of $\mathrm{Cr}$ and $\mathrm{Pb}$. For the two other elements $\mathrm{Zn}$ and $\mathrm{Sn}$, there are slight differences between SPM and sediments (figure 12 F3-F4). In the case of Zn, SPM samples appeared divided into two families, a first one for which $\mathrm{Zn}$ content increases for a rather constant iron content; a second one for which iron content increase whereas zinc content is rather stable around $1000-1300 \mathrm{ppm}$.

Further more, Sn does not behave in a similar way than the three other trace elements. Indeed, $\mathrm{Sn}$ is rather stable in Fensch sediments, with a slight increase with $\mathrm{Fe}_{2} \mathrm{O}_{3}$, whereas its concentrations are greater in SPM samples with no evident link with iron content. The different behavior of $\mathrm{Sn}$ in Fensch samples suggests that this element has a different source than iron and other trace elements $(r=0.46$ for sediments ; 0.21 for SPM). This idea is reinforced by the existence of SPM sample simultaneously highly loaded in Sn and in organic carbon (figures 9 and 11, sample of february 2003). This particular SPM sample was also noticeable for its great content in organic markers of human waste (coprostanol molecules, communication from Pierre FAURE). Thus, these different indications suggest that $\mathrm{Sn}$ has a different origin than iron and other trace elements, and furthermore Sn source could be related to the outlet effluents of the Waste Water Treatment plant.

For Downstream sediments (plots D1 to D4) the contents in $\mathrm{Zn}, \mathrm{Cr}, \mathrm{Pb}$ and $\mathrm{Sn}$ are strongly 
correlated to iron presence $(\mathrm{r}=0.88 ; 0.95 ; 0.92 ; 0.88)$. This correlation is weaker for SPM samples, suggesting that those elements become independent of iron upon remobilization or that their chemical status implies an easier re-suspension.

The particular behaviors of $\mathrm{Zn}$ and $\mathrm{Sn}$, observed for Fensch sediments, are not noticeable anymore, suggesting an homogeneization of pollutants distribution and traducing a more complete mixing of pollution sources in the downstream zone.

\section{CONCLUSION}

The study of rivers confluence and how material is distributed after waters mixing is a great piece of work as hydrodynamics majoritarily control the fate of suspended materials, themselves influenced by internal parameters of the rivers (section, bank morphology...) and by external parameters : atmospheric and terrestrial contributions. The high heterogeneous character of natural aquatic media could be approched through the study of samples collected at different times, different positions, and different compartiments of the water system. The study of the mineralogy in a classical way, using global methods such as XRD and FTIR, provided information on the fate of polluted material incoming from the Fensch river. Global chemical analyses as those carried out for this work does not really provide the transport processus of metals from SPM to sediments and from sediments to SPM. However, it revealed that SPM mineralogy and composition are close to sediments ones in the case of flood conditions whereas for lower flows SPM are more influenced by biological and organic matter. Contaminants do not always follow the mineralogy and are strongly influenced by outlets of human facilities. Although an apparent link between iron and trace elements, the nature of mineral carriers is still unknown as well as the chemical status of contaminants in the solid fraction. The correlation between iron and trace elements rises several questions. 
First of all is there a real chemical link between iron and trace elements or do they have only a common path of transportation in the aquatic system ? As it has been suggested earlier in the text, iron-phosphates such as vivianite, which are formed in the Fensch river from the different inputs, may fix or co-precipitate metallic species such as zinc. In a more precise way, what is the status of iron and other metals in those materials? How do these status evolve with remobilization, deposition or depth? Supplementary analyses, involving electronic microscopies, synchrotron related techniques will answer a part of these questions and will give further information on $\mathrm{Zn}, \mathrm{Cr}$ or $\mathrm{Sn}$ chemical status in the sediments and suspended matter.

\section{Acknowledgement}

This work was financially supported by CNRS (ECODYN program) and the Region Lorraine through the research group Zone Atelier Moselle. The authors would like to thank Laurent Michot for his help during the writting of this paper, Rhin-Meuse Water Agency for providing samples (SPM from Fensch river) and access to their data on Moselle and Fensch waters and sediments (Banque de l'Eau). A special thanks also to Emmanuel Valente and Francis Borghesi from NANCIE who set up the laboratory van before each sampling campaign. 


\section{REFERENCES}

Aucour, A.-M. et al., 2003. The Amazon River: behaviour of metals (Fe, Al, Mn) and dissolved organic matter in the initial mixing at the Rio Negro/Solimoes confluence. Chemical Geology, 197: 271-285.

Audry, S., Schäfer, J., Blanc, G. and Jouanneau, J.-M., 2004. Fifty-year sedimentary record of heavy metal pollution $(\mathrm{Cd}, \mathrm{Zn}, \mathrm{Cu}, \mathrm{Pb})$ in the Lot River reservoirs (France). Environmental Pollution, 13: 413-426.

Batson, V.L., Bertsch, P.M. and Herbert, B.E., 1996. Transport of anthropogenic uranium from sediments to surface waters during episodic storm events. Journal of Environment Quality, 25: 1129-1135.

Callender, E. and Rice, K.E., 2000. The urban environmental gradient: anthropogenic influences on the spatial and temporal distributions of lead and zinc in sediments. Environmental Science and Technology, 34(2): 232-238.

Carpentier, S., Moilleron, R., Beltran, C., Hervé, D. and Thévenot, D., 2002. Quality of dredged material in the river Seine basin (France). II. Micropollutants. The Science of the Total Environment, 299: 57-72.

Douglas, G.B., Beckett, R. and Hart, B.T., 1993. Fractionation and concentration of suspended particulate matter in natural waters. Hydrological Processes, 7: 177-191.

Galan, E. et al., 2003. Heavy metal partitioning in river sediments severely polluted by acidmine drainage in the Iberian Pyrite Belt. Applied Geochemistry, 18: 409-421.

Harland, B.J., Taylor, D. and Wither, A., 2000. The distribution of mercury and other trace metals in the sediments of the Mersey Estuary over 25 years 1974-1998. The Science of the Total Environment, 253: 45-62.

Lacal, J. et al., 2003. Study of fractionation and potential mobility of metal in sludge from pyrite mining and affected river sediments: changes in mobility over time and use of artificial ageing as a tool in environmental impact assessment. Environmental Pollution, 124: 291-305.

Long, E.R., MacDonald, D.D., Smith, S.L. and Calder, F.D., 1995. Incidence of adverse biological effects within ranges of chemical concentrations in marine and estuarine sediments. Environmental Management, 19: 81-97.

Martin, J.M. and Meybeck, M., 1979. Elemental mass balance of material carried by major world rivers. Marine Chemistry, 7: 173-206.

McCarthy, J.F. and Zachara, J.M., 1989. Subsurface transport of contaminants. Environmental Science and Technology, 23: 496-502.

McCready, S., Birch, G.F. and Long, E.R., 2006. Metallic and organic contaminants in sediments of Sydney Harbour, Australia and vicinity - A chemical dataset for evaluating sediment quality guidelines. Environment International, 32: 455-465.

McKnight, D.M. et al., 1992. Sorption of dissolved organic carbon by hydrous aluminum and iron oxides occurring at the confluence of Deer Creek with the Snake river, Summit County, Colorado. Environmental Science and Technology, 26(7): 1388-1396.

Meybeck, M., Friedrich, G., Thomas, R. and Champman, D., 1996. Chapter 6. Rivers. In: D. Chapman (Editor), Water quality assessment, 2nd edition. Chapman \& Hall, London, pp. 243-318.

Morillo, J., Usero, J. and Gracia, I., 2004. Heavy metal distribution in marine sediments from the southwest coast of Spain. Chemosphere, 55: 431-442.

Müller, J., Ruppert, H., Muramatsu, Y. and Schneider, J., 2000. Reservoir sediments - a witness of mining and industrial development (Malter Reservoir, eastern Erzgebirge, Germany). Environmental Geology, 39(12): 1341-1351.

Santiago, S. et al., 1994. Nutrient, heavy metal and organic pollutant composition of suspended and bed sediments in the Rhone river. Aquatic Sciences, 56(3): 220-242.

Sprenke, K.F. et al., 2000. Toxic metal contamination in the lateral lakes of the Coeur d'Alene River valley, Idaho. Environmental Geology, 39(6): 575-586.

Strandberg, B. et al., 1998. Occurrence, sedimentation and spatial variations of organochlorine contaminants in settling particulate matter and sediments in the Northern part of the Baltic Sea. Environmental Science and Technology, 32(12): 1754-1759. 
Stumm, W. and Morgan, J., 1995. Aquatic Chemistry: chemical equilibrium and rates in natural waters, 3rd edition. John Wiley \& sons, New York, 1040 pp.

Van Metre, P.C., Callender, E. and Fuller, C.C., 1997. Historical trends in organochlorine compounds in river basins identified using sediment cores from reservoirs. Environmental Science and Technology, 31(8): 2339-2344.

Van Metre, P.C. and Mahler, B.J., 2004. Contaminant trends in reservoir sediment cores as records of influent stream quality. Environmental Science and Technology(38): 29782986.

Vdovic, N., Billon, G., Gabelle, C. and Potdevin, J.-L., 2006. Remobilization of metals from slag and polluted sediments (case study: the canal of the Deûle river, northern France). Environmental Pollution, 141: 359-369.

Vignati, D. et al., 2003. Characterisation of bed sediments and suspension of the river Po (Italy) during normal and high flow conditions. Water Research, 37: 2847-2864.

Warren, L.A. and Zimmermann, A.P., 1994. Suspended particle grain size dynamics and their implications for trace metal sorption in the Don river. Aquatic Sciences, 56(4): 348362.

Wedepohl, K.H., 1995. The composition of the continental crust. Geochimica and Cosmochimica Acta, 59(7): 1217-1232.

Jeanneau L., Faure P., Montargés-Pelletier E., Ramelli M. 2006. Organic Geochemistry of a Highly Contaminated River and its impact on a More Important Hydrologic System. Submitted to the Science of Total Environment. 
Table and Figure Captions

Table 1: Conductivity, major and trace elements concentrations in filtered water samples from Moselle and Fensch rivers.

Table 2 Major elements contents in sediments and SPM, comparison with Upper Continental Crust composition (Wedepohl, 1995).

Table 3 : Trace elements concentrations (mg.kg-1) in sediments and SPM from Moselle and Fensch rivers. * The concentrations were compared with those collected from the Water Data Bank, for samples collected once a year from 1996 to 2004 in Uckange and Florange. Elements concentrations inUpper Continental Crust from (Wedepohl, 1995) effects-range medium ERM and effects-range-low ERL from (Long et al., 1995) 
Figure $1: \mathrm{A} /$ Catchment basin of Moselle river. B/ Catchment basin of Fensch river and rivers junction. C/ Sampling map.

Figure 2 : Moselle Hydrogramms for 2003-2005 period, mean value is the averaged flow for one month , Qd is the daily flow measurement. (*) point out the different sampling campaigns (Data published from the French National data Bank for Hydrometry and Hydrology).

Figure 3 : Analytical schema

Figure 4 : XRD pattern (a) and FTIR spectra (b) obtained from Upstream sediments (coarse fraction, a : top ; b :middle ; c :bottom). Chl : chlorite, Ver : Vermiculite, Sm :smectites, Mi : micas, I : illites, $\mathrm{K}$ : Kaolinite, Phy : phyllosilicates, C : calcite, D : dolomite, Q : quartz, F-K : K-felspars, F-Na : Na-feldspars, P : pyrite.

Figure 5: Fensch sediments, FTIR spectra (A) from coarse fraction (a: top; b :bottom) and XRD pattern (B). $\mathrm{V}$ : vivianite, Wi : wicksite, $\mathrm{H}$ : hematite, $\mathrm{M}$ : magnetite, $\mathrm{Fe}-\mathrm{Ox}$ : iron oxides, $\mathrm{S}$ : siderite, $\mathrm{A}$ : ankerite, $\mathrm{W}$ : wuestite

Figure 6: FTIR spectra of Downstream-b sediments (1) transmission mode; (2) diffuse reflectance mode.

Figure 7 : XRD patterns of coarse Downstream samples (from -a to $-\mathrm{f}, 0-2 \mathrm{~mm}$ ), $\mathrm{Mi}$ : micas, $\mathrm{I}$ : illites, Chl : chlorite, Ver : Vermiculite ;K : Kaolinite, $\mathrm{M}$ : magnetite, $\mathrm{C}$ : calcite, $\mathrm{Q}$ : quartz, F-K : K-felspars, V : vivianite, $\mathrm{H}$ : hematite, Wi : wicksite, W : wuestite, Fe-Ox : iron oxides, $\mathrm{P}:$ pyrite, $\mathrm{S}$ : siderite, $\mathrm{A}$ : ankerite.

Figure 8: FTIR spectra for four different sediments of the downstream area, focussing on stretching vibrations of $\mathrm{OH}$ groups of phyllosilicates and stretching vibrations of alkyl groups $-\mathrm{CH}_{3},-\mathrm{CH}_{2}$ and $-\mathrm{CH}$.

Figure 9 : Fensch SPM samples, major elements.

Figure $10:$ XRD patterns for three SPM samples collected during a flood event (Jan 04) : (a) Upstream ; (b) Downstream-b ; (c) Fensch. Mi : micas, illites, F-K and F-Na : potassic or sodic fedslpars, M : magentite, Ha : halite, C : Calcite, Q: Quartz, K : kaolinite, Phy : phyllosillicates, $\mathrm{H}$ : hematite

Figure 11: Variations of trace elements concentrations in twelve samples of Fensch SPM from 2003 to 2005 . * :for this sample $\mathrm{Zn}$ concentration (9086 ppm) was divided by 4 for figure clearness.

Figure 12 : Correlations of trace elements contents in seidments and $\mathrm{SPM}$ with $\mathrm{Fe}_{2} \mathrm{O}_{3}$ content. Left column : Fensch samples. Right column : Downstream samples. 


\section{table 1}

\begin{tabular}{|c|c|c|c|c|c|c|c|c|c|c|c|c|c|c|c|c|c|c|c|c|}
\hline \multirow[b]{3}{*}{ majors } & \multicolumn{4}{|c|}{$01-2004, \mathrm{Q}=540 \mathrm{~m}^{3} \cdot \mathrm{s}^{-1}$} & \multicolumn{4}{|c|}{$02-2005, \mathrm{Q}=106 \mathrm{~m}^{3} \cdot \mathrm{s}^{-1}$} & \multicolumn{6}{|c|}{$06-2005, \mathrm{Q}=59.7 \mathrm{~m}^{3} \cdot \mathrm{s}^{-1}$} & \multicolumn{6}{|c|}{$07-2005, \mathrm{Q}=36.8 \mathrm{~m}^{3} \cdot \mathrm{s}^{-1}$} \\
\hline & $\mathrm{Up}$ & Ds-c & Fensch- & $f_{\text {f }}$ & $\mathrm{Up}$ & Ds-c & & $f_{\text {s }}$ & $\mathrm{Up}$ & & & & $f_{\text {f }}$ & $f$ & $\mathrm{Up}$ & Ds-c & Ds-e & & $f_{\text {f }}$ & $f_{\text {。 }}$ \\
\hline & $m g \cdot t^{t}$ & $m g .1$ & $m g . l^{\prime}$ & & $m g .1^{t}$ & $m g \cdot l^{t}$ & $m g . l^{\prime \prime}$ & & $m g .1^{\prime}$ & $m g .1$ & $m g .1^{\prime}$ & $m g . l^{\prime}$ & & & $m g . l^{\prime}$ & $m g .1$ & $m g . l^{\prime}$ & $m g .1^{-1}$ & & \\
\hline $\begin{array}{l}\mathrm{Si} \\
\mathrm{Ca}\end{array}$ & $\begin{array}{c}3.00 \\
159.04\end{array}$ & $\begin{array}{c}3.21 \\
159.38\end{array}$ & $\begin{array}{c}4.63 \\
144.46\end{array}$ & 0.12 & $\begin{array}{c}3.13 \\
216.81\end{array}$ & $\begin{array}{c}4.2 \\
199.3\end{array}$ & $\begin{array}{c}5.13 \\
185.2\end{array}$ & $\begin{array}{l}0.51 \\
0.55\end{array}$ & $\begin{array}{c}1.55 \\
158.24\end{array}$ & $\begin{array}{c}2.92 \\
144.02\end{array}$ & $\begin{array}{c}1.89 \\
157.755\end{array}$ & $\begin{array}{c}3.88 \\
121.916\end{array}$ & $\begin{array}{l}0.59 \\
0.39\end{array}$ & $\begin{array}{l}0.15 \\
0.01\end{array}$ & $\begin{array}{c}1.65 \\
138.8\end{array}$ & $\begin{array}{c}3.24 \\
147.15\end{array}$ & $\begin{array}{c}2.29 \\
141.59\end{array}$ & $\begin{array}{c}4.11 \\
140.91\end{array}$ & $\begin{array}{l}0.65 \\
3.96\end{array}$ & $\begin{array}{l}0.26 \\
1.32\end{array}$ \\
\hline $\begin{array}{c}\mathrm{Na} \\
\mathrm{Mg} \\
\mathrm{K} \\
\mathrm{Fe} \\
\mathrm{P}\end{array}$ & $\begin{array}{l}66.68 \\
11.36 \\
4.66 \\
<\mathrm{dl} \\
<\mathrm{dl}\end{array}$ & $\begin{array}{l}70.65 \\
12.05 \\
7.41 \\
<\mathrm{dl} \\
<\mathrm{dl}\end{array}$ & $\begin{array}{c}89.4 \\
16.94 \\
22.08 \\
<\mathrm{dl} \\
<\mathrm{dl}\end{array}$ & $\begin{array}{c}0.02 \\
0.17 \\
0.11 \\
0.16 \\
- \\
-\end{array}$ & $\begin{array}{c}106.78 \\
19.21 \\
6.13 \\
<\mathrm{dl} . \\
0.22\end{array}$ & $\begin{array}{l}110.8 \\
22.7 \\
12.7 \\
<\mathrm{dl} . \\
0.18\end{array}$ & $\begin{array}{l}120.5 \\
28.9 \\
23.9 \\
<\mathrm{dl} . \\
0.14\end{array}$ & $\begin{array}{c}0.29 \\
0.37 \\
0.37 \\
- \\
0.41\end{array}$ & $\begin{array}{c}100.88 \\
14.68 \\
5.55 \\
<\mathrm{dl} \\
0.13\end{array}$ & $\begin{array}{c}94.79 \\
16.70 \\
12.91 \\
<\mathrm{dl} \\
0.15\end{array}$ & $\begin{array}{l}99.53 \\
15.34 \\
7.91 \\
<\mathrm{dl} \\
0.12\end{array}$ & $\begin{array}{c}85.15 \\
15.40 \\
17.67 \\
<\mathrm{dl} \\
0.15\end{array}$ & $\begin{array}{c}0.39 \\
2.82 \\
0.61 \\
- \\
1.16\end{array}$ & $\begin{array}{c}0.09 \\
0.92 \\
0.19 \\
-\end{array}$ & $\begin{array}{l}122.1 \\
17.47 \\
6.54 \\
<\mathrm{dl} \\
0.15\end{array}$ & $\begin{array}{c}118.89 \\
19.09 \\
13.86 \\
<\mathrm{dl} \\
0.37\end{array}$ & $\begin{array}{c}122.66 \\
18.16 \\
9.56 \\
<\mathrm{dl} \\
0.23\end{array}$ & $\begin{array}{c}111.51 \\
19.11 \\
17.2 \\
<\mathrm{dl} \\
0.27\end{array}$ & $\begin{array}{l}0.30 \\
0.99 \\
0.69\end{array}$ & $\begin{array}{c}-0.06 \\
0.43 \\
0.28\end{array}$ \\
\hline Cond. & 1532 & 1285 & 1163 & 0.67 & 1686 & 1593 & 1552 & 0.69 & 1622 & 1481 & 1610 & 1269 & 0.4 & $\begin{array}{l}0.74 \\
0.03\end{array}$ & 1685 & 1570 & 1620 & 1362 & 0.36 & 0.20 \\
\hline traces & $\mu g .1$ & $\mu g . t$ & $\mu g . l^{\prime}$ & & $\mu g .1$ & $\mu g .1$ & $\mu g . l^{\prime}$ & & $\mu g . l$ & $\mu g . t$ & $\mu g . l^{\prime}$ & $\mu g .1$ & & & $\mu g . l^{\prime}$ & $\mu g . t$ & $\mu g . l^{\prime}$ & $\mu g . t$ & & \\
\hline $\begin{array}{l}\mathrm{As} \\
\mathrm{Al} \\
\mathrm{Mn} \\
\mathrm{Ba} \\
\mathrm{Cr}\end{array}$ & $\begin{array}{c}- \\
4.16 \\
30,25 \\
41.8 \\
10.3\end{array}$ & $\begin{array}{c}- \\
2.24 \\
61,10 \\
40.9 \\
7.4\end{array}$ & $\begin{array}{c}- \\
2.17 \\
100.23 \\
26.7 \\
4.9\end{array}$ & $\begin{array}{l}- \\
0.96 \\
0.42 \\
0.06 \\
0.54\end{array}$ & $\begin{array}{l}1.1 \\
5.75 \\
7,22 \\
57.1 \\
11.1\end{array}$ & $\begin{array}{c}1.1 \\
8.6 \\
10,42 \\
47.2 \\
9.6\end{array}$ & $\begin{array}{c}1.6 \\
9.98 \\
24,21 \\
40.1 \\
7.9\end{array}$ & $\begin{array}{c}0 \\
0.67 \\
0.48 \\
0.58 \\
0.49\end{array}$ & $\begin{array}{c}1.0 \\
47.48 \\
14.95 \\
56.42 \\
11.4\end{array}$ & $\begin{array}{c}1.0 \\
71.66 \\
5.73 \\
42.29 \\
6.9\end{array}$ & $\begin{array}{c}1.0 \\
67.41 \\
4.23 \\
54.98 \\
13.42\end{array}$ & $\begin{array}{c}1.1 \\
179 \\
11.08 \\
27.56 \\
7.66\end{array}$ & $\begin{array}{c}0 \\
2.39 \\
0.21 \\
0.49 \\
0.40\end{array}$ & $\begin{array}{c}0 \\
2.78 \\
0.18 \\
0.05\end{array}$ & $\begin{array}{c}1.1 \\
3.75 \\
37.23 \\
49.58 \\
9.26\end{array}$ & $\begin{array}{c}1.15 \\
11.0 \\
115.71 \\
40.15 \\
8.68\end{array}$ & $\begin{array}{c}1.12 \\
7.07 \\
74.3 \\
48.07 \\
9.35\end{array}$ & $\begin{array}{c}1.20 \\
10.83 \\
<\mathrm{dl} \\
29.10 \\
6.76\end{array}$ & $\begin{array}{c}0.5 \\
1.02 \\
-2.44 \\
0.46 \\
0.23\end{array}$ & $\begin{array}{c}0.2 \\
0.47 \\
-1.15 \\
0.07 \\
-0.03\end{array}$ \\
\hline $\mathrm{Sr}$ & 504 & 534 & 708 & 2.47 & 879.6 & 935.8 & 1027.3 & 0.38 & 757.68 & 787.67 & 854.32 & 667.50 & 0.33 & 0.54 & 842.29 & 837.30 & 890.55 & 772.41 & 0.07 & -0.69 \\
\hline $\mathrm{Rb}$ & 2.9 & 12.3 & 43.3 & 0.07 & 4.5 & 17.5 & 46.21 & 0.31 & 5.47 & 22.84 & 11 & 33.11 & 0.63 & 0.2 & 5.98 & 28.49 & 17.21 & 34.0 & 0.80 & 0.40 \\
\hline $\mathrm{U}$ & 0.34 & 2.17 & 0.75 & 084 & 0.37 & 0.57 & 0.6 & 0.86 & 0.30 & 0.29 & 0.22 & 0.16 & 0.05 & 0.57 & 0.49 & 0.53 & 0.53 & 0.51 & 1.6 & 1.65 \\
\hline Co & 0.54 & 0.416 & 0.621 & $\begin{array}{c}0.04 \\
31\end{array}$ & 0.4 & 0.44 & 0.54 & 0.23 & 0.52 & 0.62 & 0.61 & 0.65 & 0.76 & 0.72 & 0.55 & 0.70 & 0.67 & 6.76 & 0.99 & 0.79 \\
\hline $\mathrm{Cu}$ & 2.1 & 0.79 & 1.06 & 1.25 & 4.8 & 5.66 & 3.4 & 0.63 & 2.31 & 2.79 & 2.46 & 2.86 & 0.88 & 0.27 & 1.85 & 1.60 & 1.90 & 1.59 & 0.93 & -0.18 \\
\hline $\mathrm{Ni}$ & 6.5 & 3.93 & 8.12 & $\begin{array}{c}- \\
1.67\end{array}$ & 6.1 & 6.2 & 7.5 & 0.07 & 7.97 & 10.23 & 8.95 & 8.46 & 4.63 & 2.02 & 9.35 & 12.29 & 12.02 & 12.04 & 1.09 & 0.99 \\
\hline $\mathrm{Zn}$ & 1.6 & 13.5 & 7.03 & 2.19 & 4.38 & 9.9 & 38.7 & 0.16 & 12.20 & 17.93 & 4.63 & 41.51 & 0.20 & $0 . \overline{26}$ & 3.00 & 15.49 & 10.54 & 21.46 & 0.68 & 0.41 \\
\hline $\begin{array}{l}\mathrm{Cs} \\
\mathrm{Pb}\end{array}$ & $\begin{array}{c}0.024 \\
<\mathrm{dl}\end{array}$ & $\begin{array}{l}7.86 \\
<\mathrm{dl}\end{array}$ & $\begin{array}{c}4 \\
<\mathrm{dl}\end{array}$ & 1.98 & $\begin{array}{l}0.18 \\
0.11\end{array}$ & 1.6 & 11.1 & 0.13 & $\begin{array}{l}0.22 \\
030\end{array}$ & 3.32 & 1.0 & $\begin{array}{l}3.62 \\
0.36\end{array}$ & 0.91 & 0.23 & 0.17 & 3.23 & 1.84 & 2.69 & 1.21 & $\begin{array}{r}0.66 \\
-0.54\end{array}$ \\
\hline $\mathrm{Pb}$ & $<\mathrm{dl}$ & $<\mathrm{dl}$ & $<\mathrm{dl}$ & - & 0.11 & 0.35 & 0.25 & 1.71 & 0.30 & 0.42 & 0.21 & 0.36 & 1.87 & 1.36 & 0.09 & 0.07 & 0.12 & 0.03 & 0.39 & -0.54 \\
\hline $\mathrm{Cd}$ & $<\mathrm{dl}$ & 0.114 & $<\mathrm{dl}$ & - & 0.1 & 0.12 & 0.1 & -0.9 & $<\mathrm{dl}$ & $<\mathrm{dl}$ & 0.01 & 0.05 & - & & $<\mathrm{dl}$ & 0.11 & 0.07 & 0.06 & - & \\
\hline
\end{tabular}


Table 2

\begin{tabular}{|c|c|c|c|c|c|c|}
\hline & $\underset{\%}{\mathrm{SiO}_{2}}$ & $\begin{array}{c}\mathbf{A l}_{2} \mathbf{O}_{3} \\
\%\end{array}$ & $\begin{array}{c}\mathbf{F e}_{2} \mathbf{O}_{3} \\
\%\end{array}$ & $\underset{\%}{\mathbf{M g O}}$ & $\underset{\%}{\mathbf{C a O}}$ & $\begin{array}{c}\text { C.Org } \\
\%\end{array}$ \\
\hline Upstream 0-2 mm & $54.03 \pm 3.93$ & $10.45 \pm 1.18$ & $6.21 \pm 1.38$ & $1.18 \pm 0.28$ & $8.72 \pm 0.71$ & $2.48 \pm 0.9$ \\
\hline Upstream 0-50 $\mu \mathrm{m}$ & $49.14 \pm 1.25$ & $12.75 \pm 0.68$ & $7.71 \pm 1.51$ & $1.77 \pm 0.08$ & $7.41 \pm 1.11$ & $2.63 \pm 0.29$ \\
\hline Upstream-s & 25.12 & 9.29 & 3.93 & 2.26 & 11.44 & n.d. \\
\hline Fensch 0-2 mm & $32.48 \pm 11.7$ & $4.77 \pm 1.2$ & $24.24 \pm 13.5$ & $0.8 \pm 0.15$ & $15.64 \pm 1.9$ & $2.81 \pm 1.5$ \\
\hline Fensch $0-50 \mu \mathrm{m}$ & $24.01 \pm 10.3$ & $5.24 \pm 1.9$ & $31.03 \pm 21.1$ & $0.25 \pm 0.11$ & $14.43 \pm 3.8$ & $3.2 \pm 1.6$ \\
\hline Fensch-s & $22.5 \pm 7.6$ & $5.03 \pm 1$ & $14.53 \pm 5.3$ & $1.3 \pm 0.3$ & $18.2 \pm 2.9$ & $6 \pm 3$ \\
\hline Downstream-a 0-2 mm & $48.1 \pm 0.6$ & $10.3 \pm 1.3$ & $8.8 \pm 1.2$ & $1.3 \pm 0.2$ & $10.0 \pm 1.7$ & $3.3 \pm 0.5$ \\
\hline Downstream-b 0-2 mm & $16.2 \pm 3.8$ & $6.1 \pm 1.6$ & $38.8 \pm 2.8$ & $1 \pm 0.2$ & $10.0 \pm 1.2$ & $7.5 \pm 1.4$ \\
\hline Downstream-c 0-2 mm & 50.53 & 18.64 & 7.19 & 2.28 & 5.54 & 0.8 \\
\hline Downstream-d 0-2 mm & 43.01 & 9.99 & 8.94 & 1.44 & 10.16 & 5.23 \\
\hline Downstream-e 0-2 mm & 36.2 & 7.96 & 18.53 & 1.04 & 8.78 & 8.2 \\
\hline Downstream-f 0-2 mm & 58.93 & 5.85 & 7.87 & 0.79 & 13.84 & 0.77 \\
\hline Downstream-a 0-50 $\mu \mathrm{m}$ & $45.6 \pm 1.9$ & $11.1 \pm 0.6$ & $11 \pm 1.2$ & $1.5 \pm 0.2$ & $9.2 \pm 0.8$ & $2.8 \pm 0.6$ \\
\hline Downstream-b 0-50 $\mu \mathrm{m}$ & $13 \pm 5.1$ & $5.1 \pm 2.0$ & $43.3 \pm 3.8$ & $1.0 \pm 0.2$ & $10.9 \pm 1.7$ & $6.6 \pm 1.7$ \\
\hline Downstream-d 0-50 $\mu \mathrm{m}$ & 42.92 & 10.39 & 8.73 & 1.61 & 10.56 & 4.17 \\
\hline Downstream-e 0-50 $\mu \mathrm{m}$ & 19.90 & 6.13 & 30.40 & 0.90 & 9.50 & 13.01 \\
\hline Downstream-f 0-50 $\mu \mathrm{m}$ & 32.75 & 9.28 & 16.75 & 1.47 & 13.96 & 3.79 \\
\hline Downstream-s-c & $18.3 \pm 5.8$ & $5.9 \pm 2.4$ & $4.9 \pm 0.3$ & $2.26 \pm 0.1$ & $14.63 \pm 2.2$ & $4.07 \pm 0.4$ \\
\hline Downstream s-e & $18.9 \pm 9.6$ & $5.58 \pm 2.8$ & $4.68 \pm 2.9$ & $2.27 \pm 0.3$ & $16.17 \pm 5.6$ & $4.15 \pm 0.3$ \\
\hline Upper continental crust & 61.5 & 15.1 & 6.28 & 3.7 & 5.5 & - \\
\hline
\end{tabular}




\section{Table 3}

\begin{tabular}{|c|c|c|c|c|c|c|c|}
\hline & $\begin{array}{c}\mathrm{As} \\
\mathrm{mg} \cdot \mathrm{kg}\end{array}$ & $\begin{array}{c}\mathrm{Cr} \\
\mathrm{mg} \cdot \mathrm{kg}^{\prime}\end{array}$ & $\begin{array}{c}\mathrm{Cu} \\
m g \cdot k g\end{array}$ & $\begin{array}{c}\mathbf{N i} \\
m g . k g^{\prime}\end{array}$ & $\begin{array}{c}\mathbf{P b} \\
m g \cdot k g\end{array}$ & $\underset{m g \cdot k g^{\prime}}{\operatorname{Sn}}$ & $\underset{m g \cdot k g^{\prime}}{\mathbf{Z n}}$ \\
\hline UCKANGE 0-2 mm* & $13 \pm 9$ & $48 \pm 21$ & $36 \pm 15$ & $29 \pm 11$ & $117 \pm 62$ & - & $345 \pm 177$ \\
\hline Upstream 0-2 mm & $23 \pm 4$ & $111 \pm 17$ & $39 \pm 12$ & $37 \pm 8$ & $137 \pm 117$ & $10 \pm 3$ & $498 \pm 350$ \\
\hline Upstream 0-50 mm & $26 \pm 6$ & $127 \pm 19$ & $54 \pm 4$ & $53 \pm 8$ & $188 \pm 150$ & $19 \pm 17$ & $610 \pm 460$ \\
\hline Upstream-s & 21.9 & 70.4 & 24.8 & 36.4 & 60 & 7.8 & 97.8 \\
\hline FLORANGE 0-2 mm* & $25 \pm 15$ & $300 \pm 219$ & $74 \pm 57$ & $64 \pm 17$ & $247 \pm 119$ & - & $2300 \pm 901$ \\
\hline Fensch $0-2 \mathrm{~mm}$ & $95 \pm 96$ & $693 \pm 422$ & $111 \pm 43$ & $124 \pm 85$ & $399 \pm 328$ & $361 \pm 198$ & $2765 \pm 1756$ \\
\hline Fensch 0-50 mm & $116 \pm 109$ & $808 \pm 505$ & $147 \pm 30$ & $172 \pm 101$ & $467 \pm 274$ & $577 \pm 155$ & $3636 \pm 1343$ \\
\hline Fensch-s & $41 \pm 8$ & $344 \pm 149$ & $160 \pm 94$ & $68 \pm 21$ & $233 \pm 222$ & $838 \pm 664$ & $2319 \pm 2161$ \\
\hline Downstream-a 0-2 mm & $35 \pm 6$ & $314 \pm 119$ & $63 \pm 9$ & $57 \pm 8$ & $233 \pm 97$ & $109 \pm 62$ & $1638 \pm 1102$ \\
\hline Downstream-b 0-2 mm & $332 \pm 34$ & $1342 \pm 90$ & $246 \pm 46$ & $305 \pm 55$ & $1377 \pm 269$ & $2317 \pm 1363$ & $5551 \pm 862$ \\
\hline Downstream-c 0-2 mm & 13.24 & 123.6 & 24.27 & 60.61 & 22.79 & 7.6 & 132.8 \\
\hline Downstream-d 0-2 mm & 26.54 & 219.3 & 65.26 & 47.74 & 138.48 & 158 & 158 \\
\hline Downstream-e 0-2 mm & 100.4 & 758.4 & 135.3 & 103.1 & 428.62 & 741.6 & 2138 \\
\hline Downstream-f 0-2 mm & 30.99 & 296.6 & 28.9 & 54.53 & 57.42 & 30.98 & 386.2 \\
\hline Downstream-a 0-50 mm & $47 \pm 10$ & $312 \pm 119$ & $77 \pm 9$ & $73 \pm 7$ & $362 \pm 144$ & $162 \pm 78$ & $2374 \pm 1357$ \\
\hline Downstream-b 0-50 mm & $370 \pm 35$ & $1540 \pm 444$ & $271 \pm 53$ & $352 \pm 41$ & $1406 \pm 285$ & $2430 \pm 1331$ & $5642 \pm 869$ \\
\hline Downstream-d 0-50 mm & 25.93 & 203.5 & 72.93 & 53.48 & 178.88 & 216.5 & 216.5 \\
\hline Downstream-e 0-50 mm & 175.3 & 1155 & 129.9 & 91.58 & 270.7 & 286 & 2965 \\
\hline Downstream-f 0-50 mm & 62.59 & 342.5 & 223.3 & 159.7 & 641.09 & 1268 & 1766 \\
\hline Downstream-s-c & $24 \pm 5$ & $68 \pm 79$ & $14 \pm 13$ & $25 \pm 17$ & $55 \pm 47$ & $160 \pm 259$ & $754 \pm 553$ \\
\hline Downstream-s-e & $22 \pm 7$ & $97 \pm 87$ & $37 \pm 41$ & $28 \pm 16$ & $60 \pm 45$ & $164 \pm 206$ & $760 \pm 471$ \\
\hline Upper Continental Crust & 2.0 & 35 & 14.3 & 18.6 & 17 & 2.5 & 52 \\
\hline$E R L$ & 8.2 & 81 & 34 & 20.9 & 46.7 & - & 150 \\
\hline$E R M$ & 70 & 370 & 270 & 51.6 & 218 & - & 410 \\
\hline A. Alert value & 29 & 100 & 36 & 35 & 85 & - & 140 \\
\hline I. Intervention value & 55 & 380 & 190 & 210 & 530 & - & 720 \\
\hline
\end{tabular}




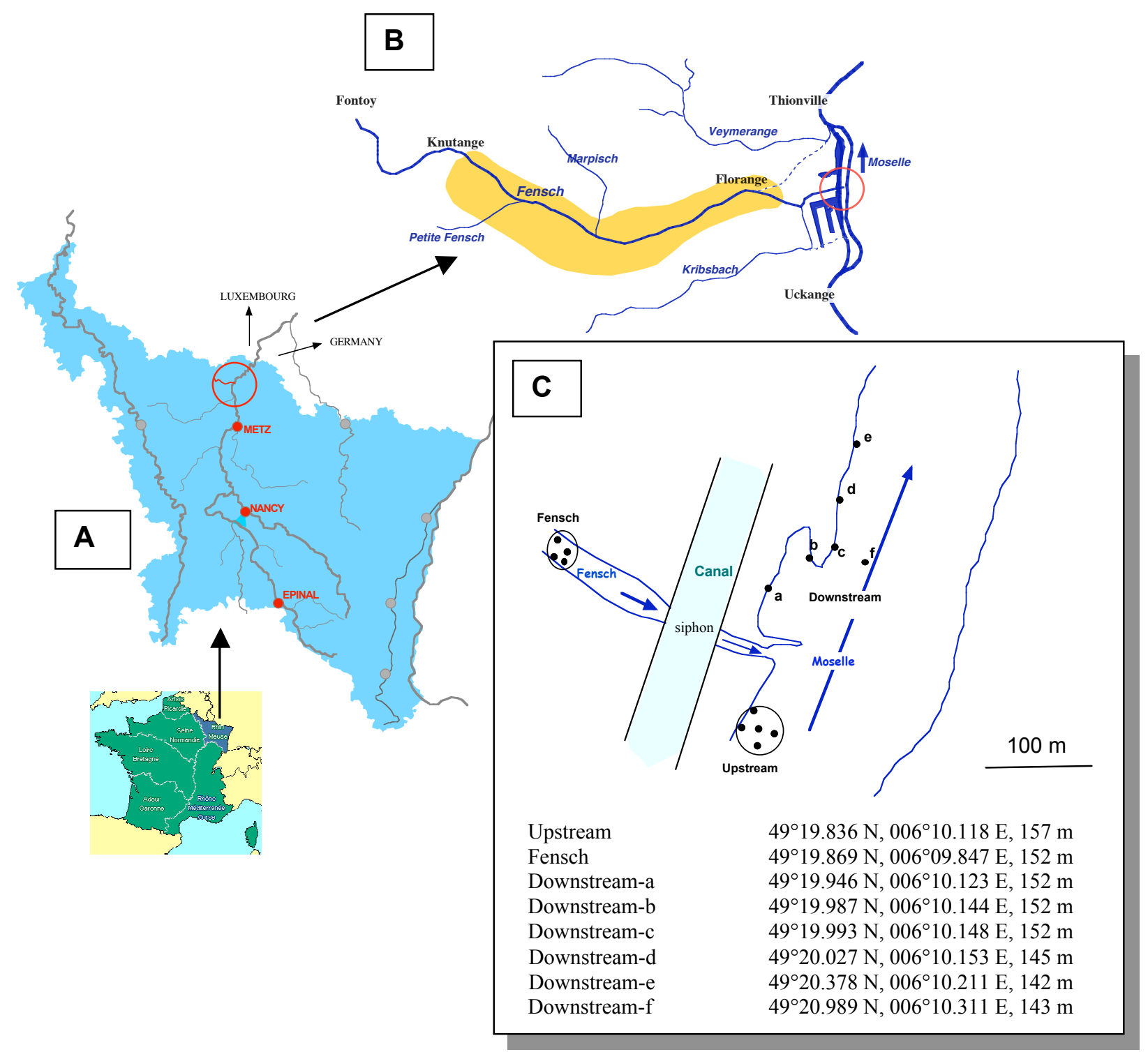

Figure 1 


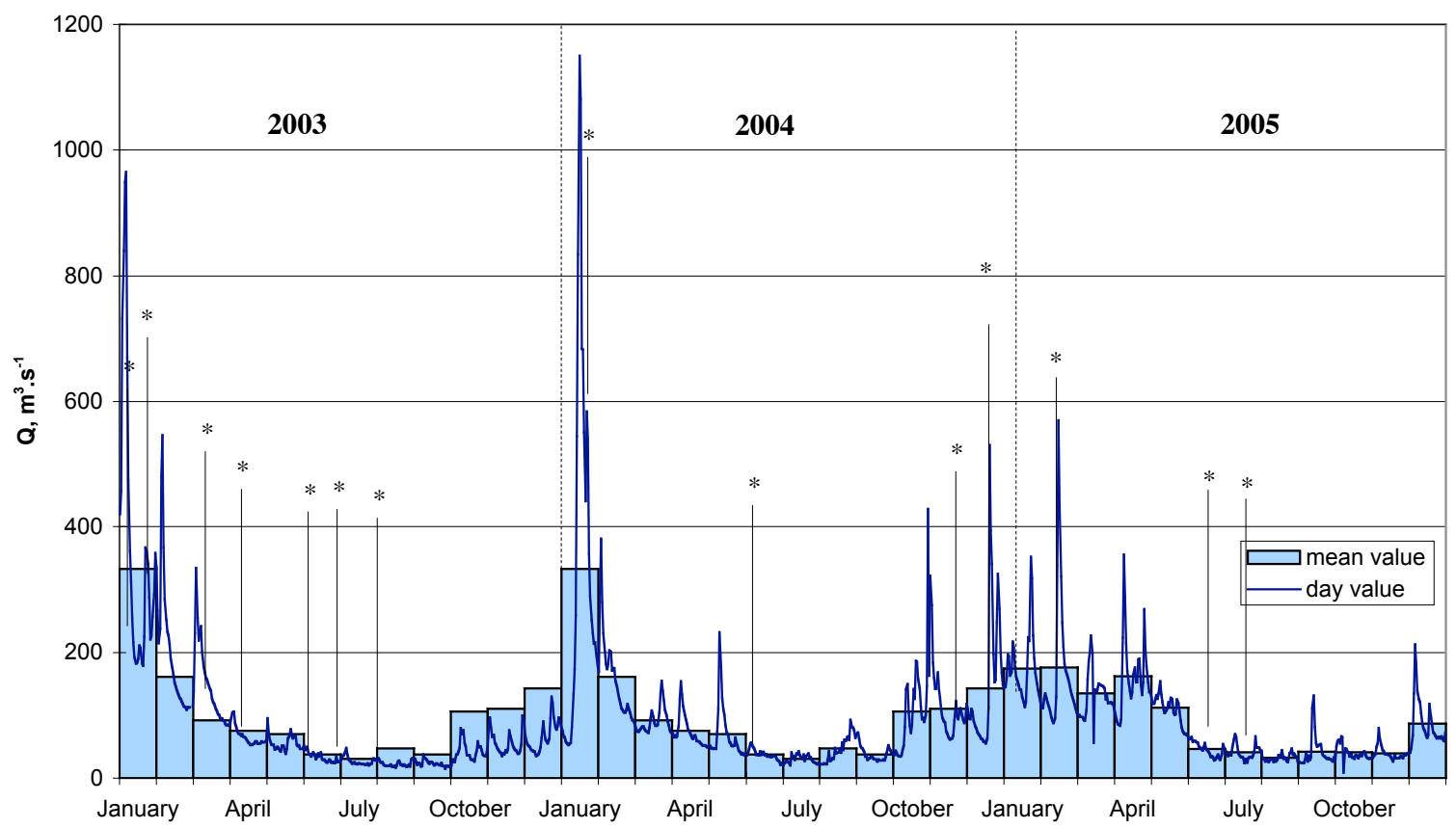

figure 2 


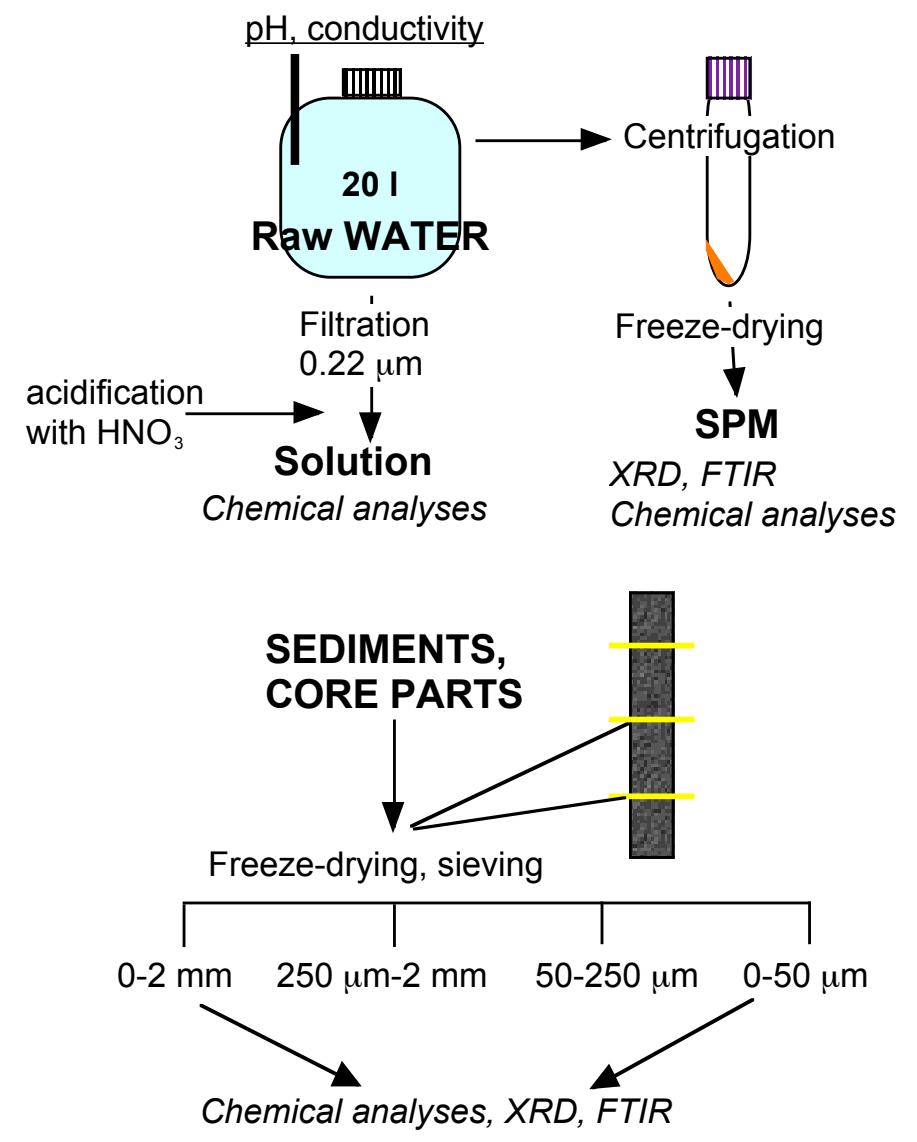

Figure 3 


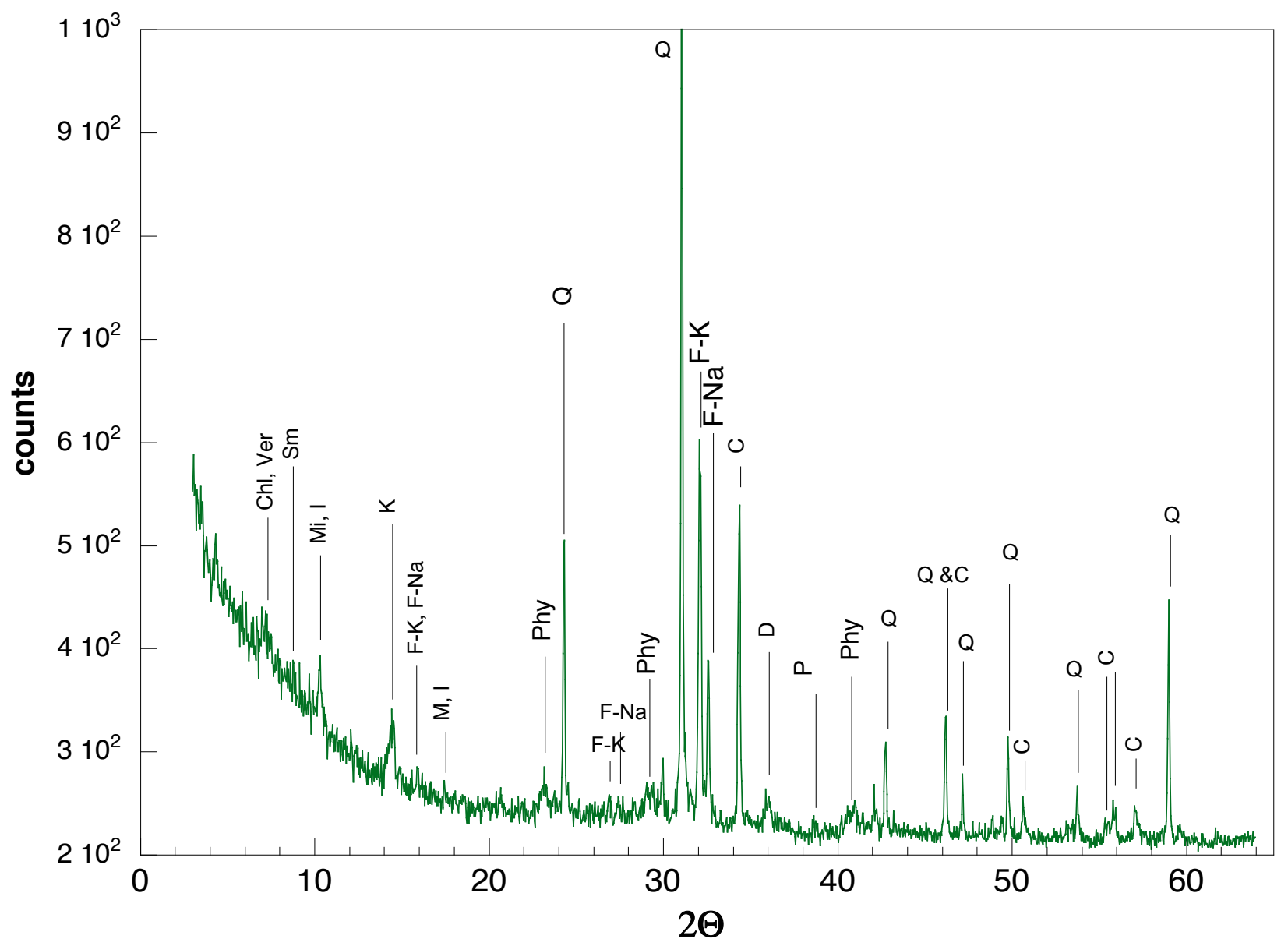

Figure 4a 


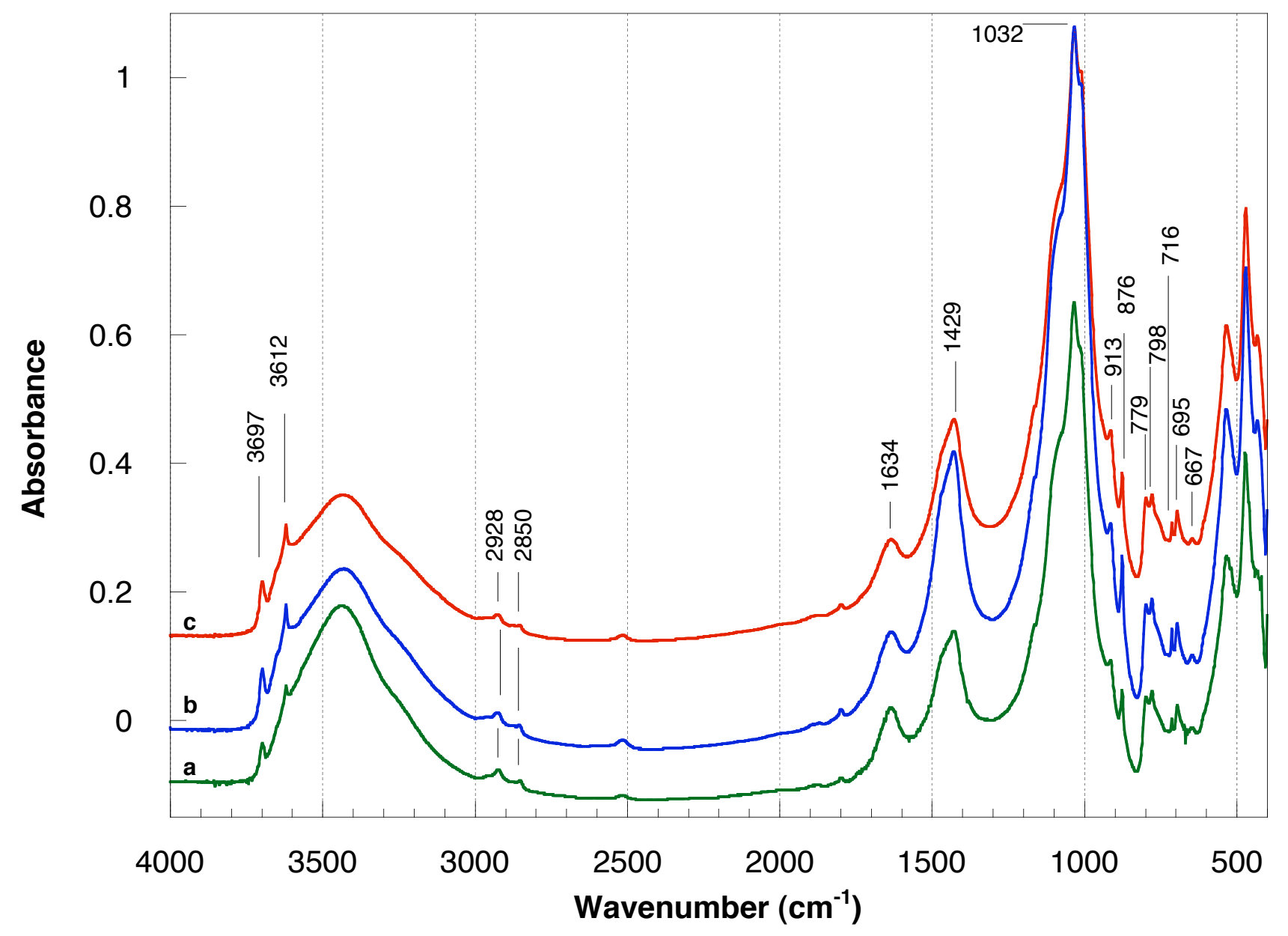

figure $4 b$ 


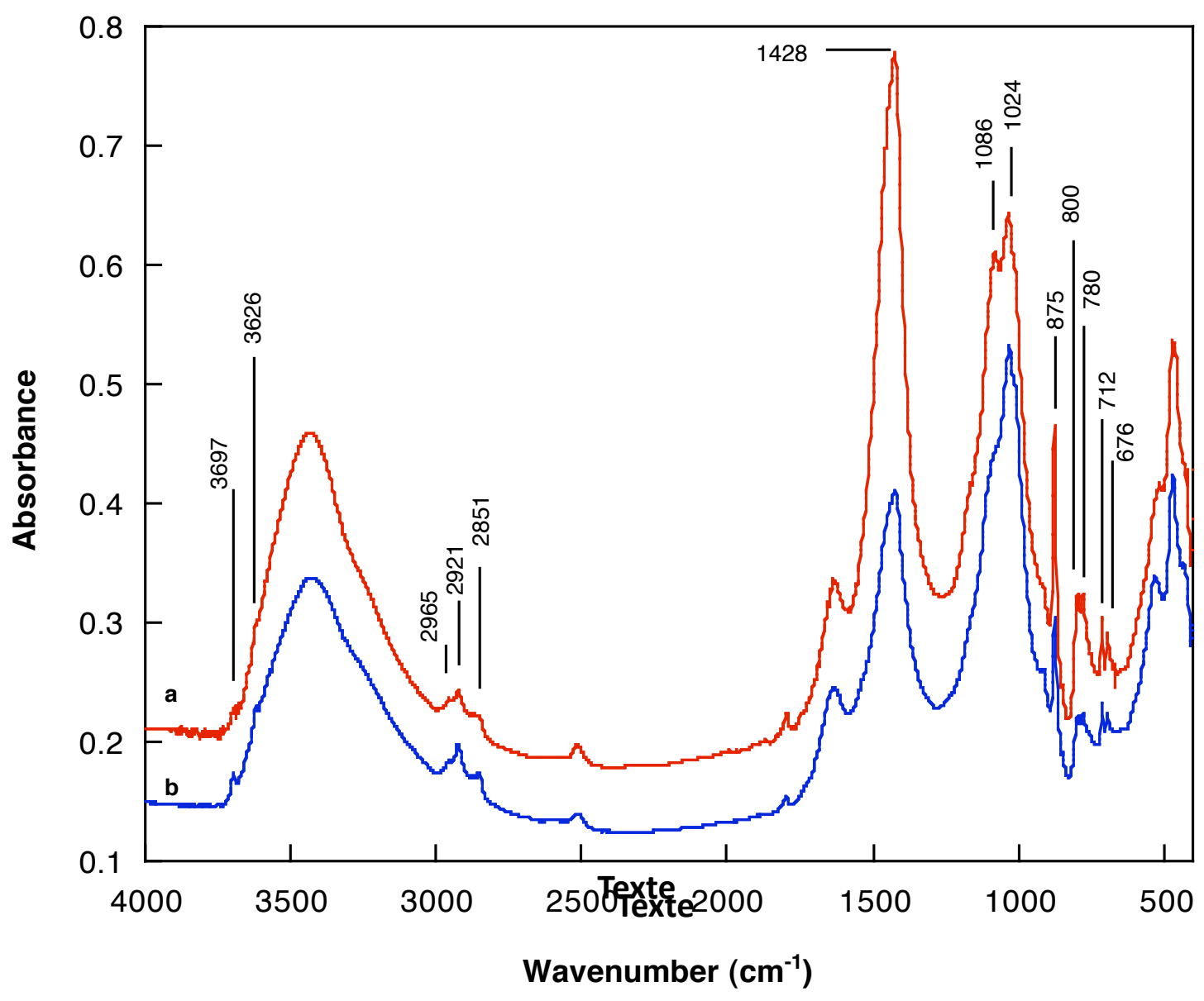

Figure 5a 


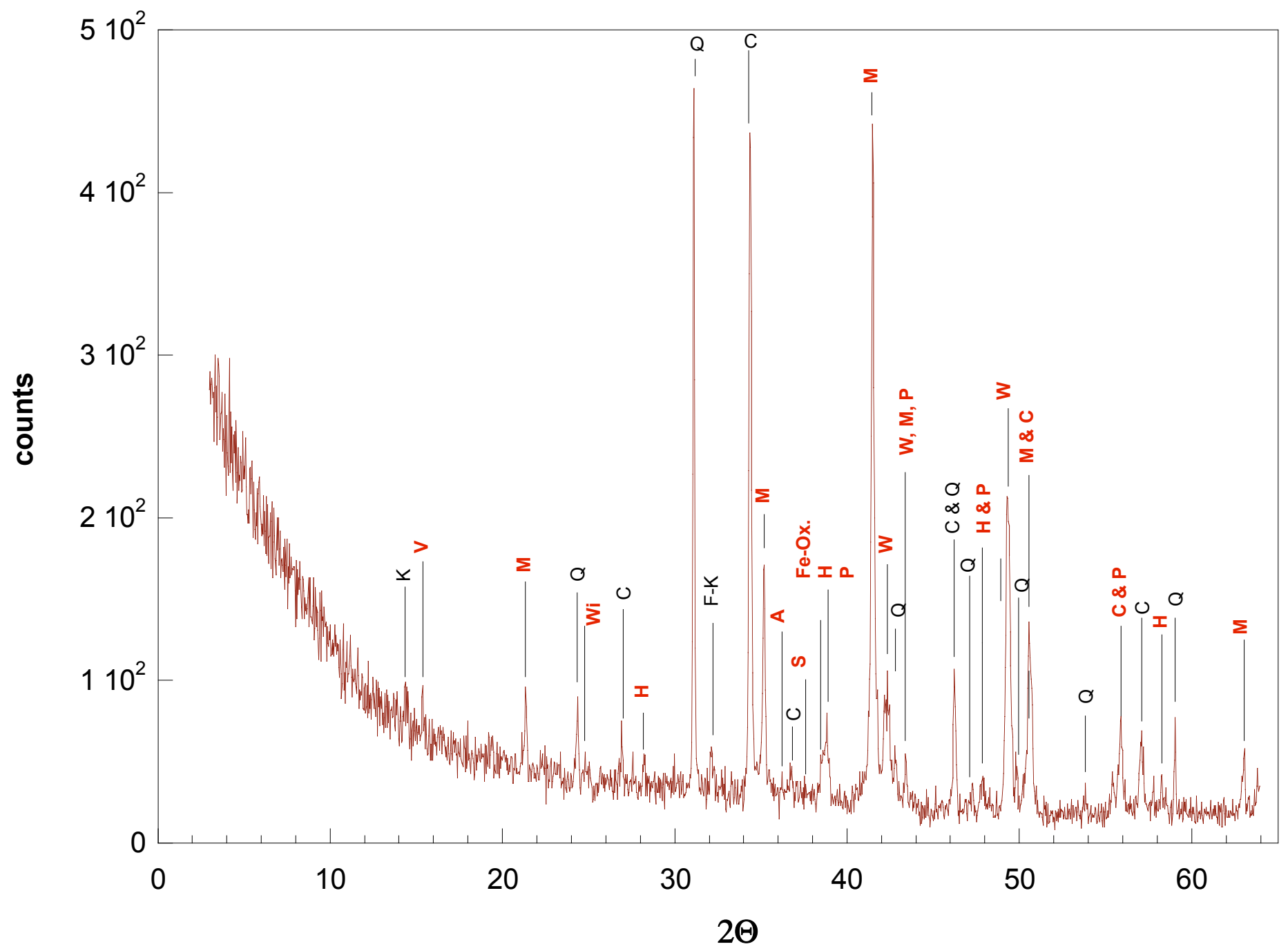

Figure 5b 

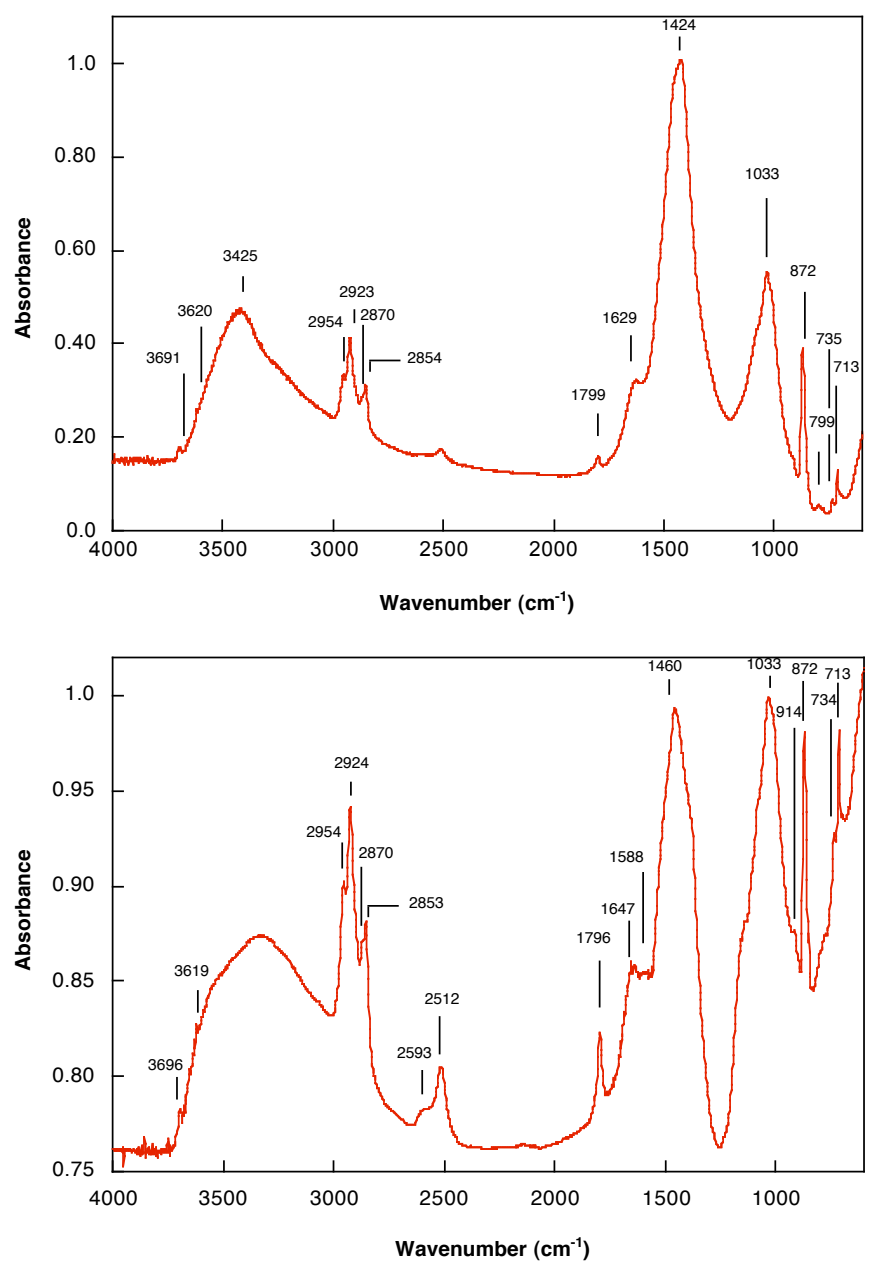

Figure 6 


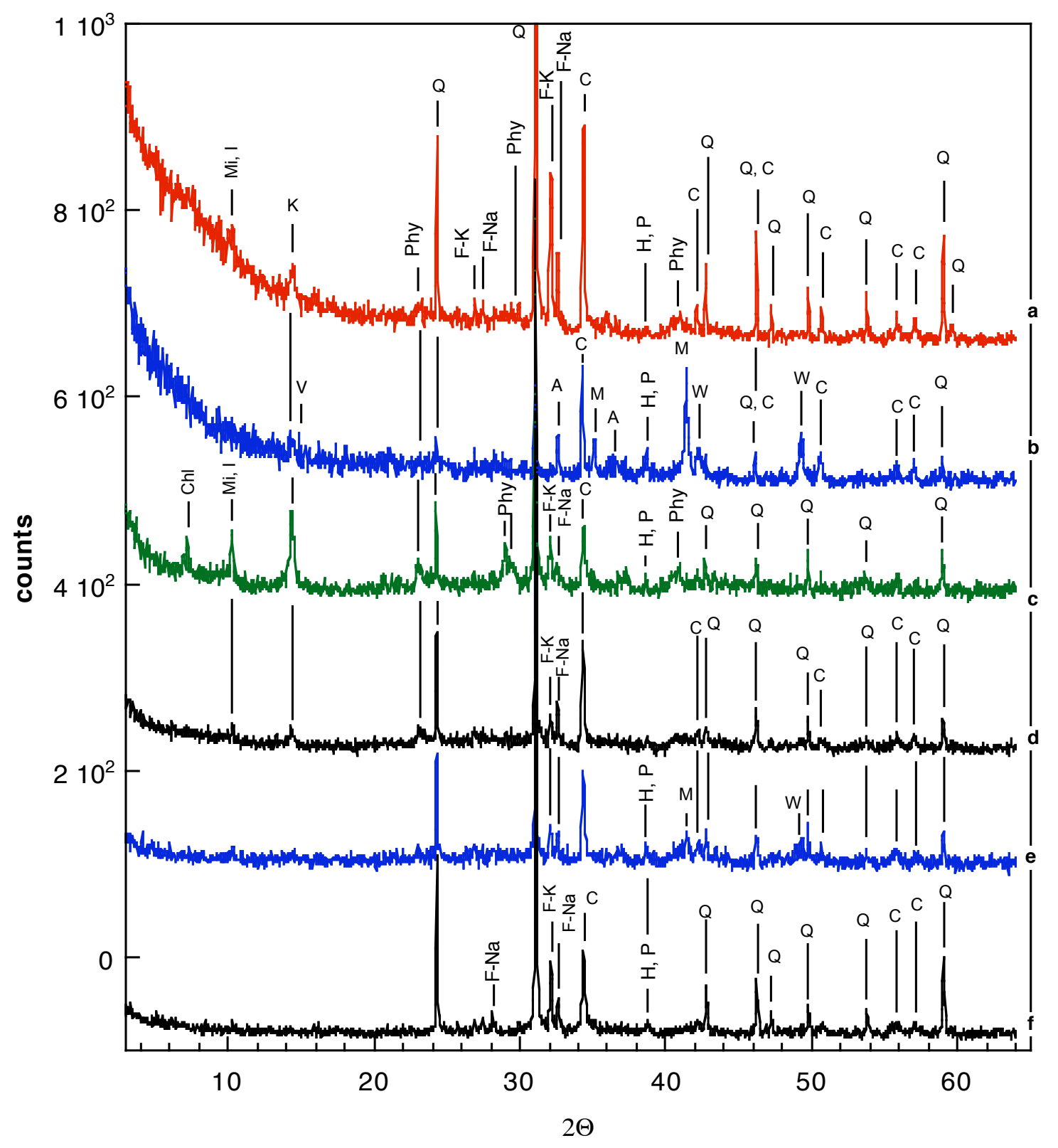

Figure 7 


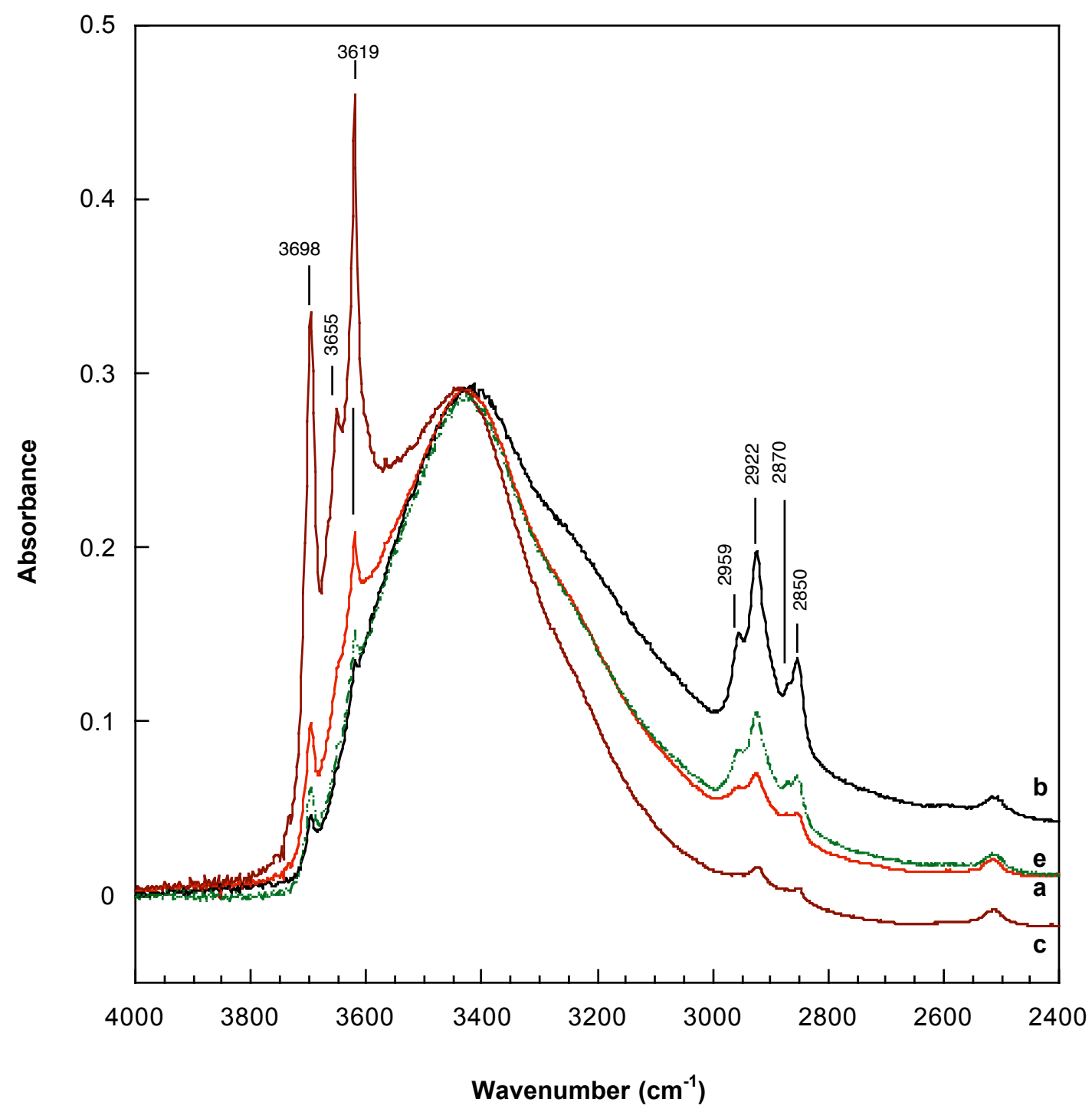

figure 8 

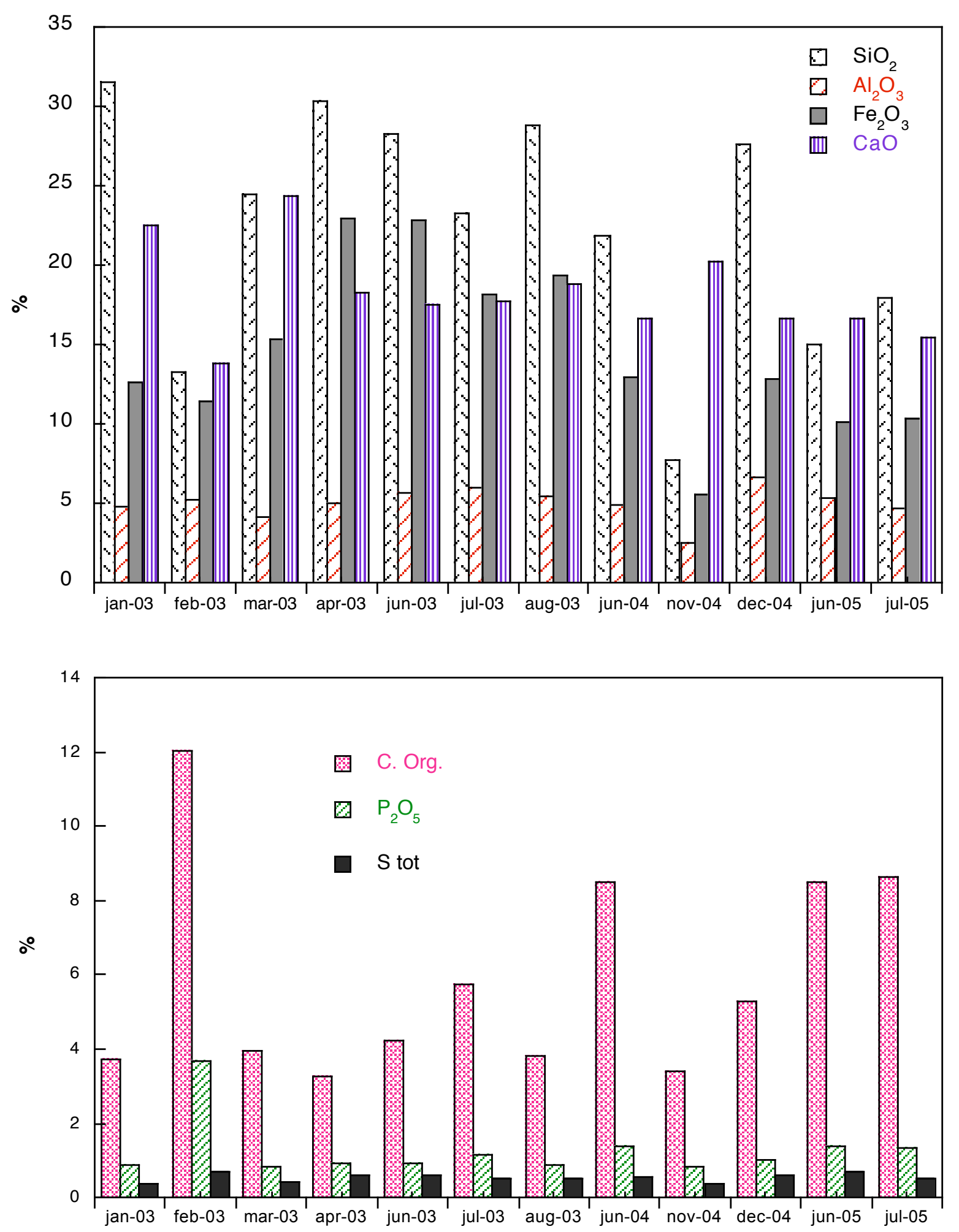

figure 9 


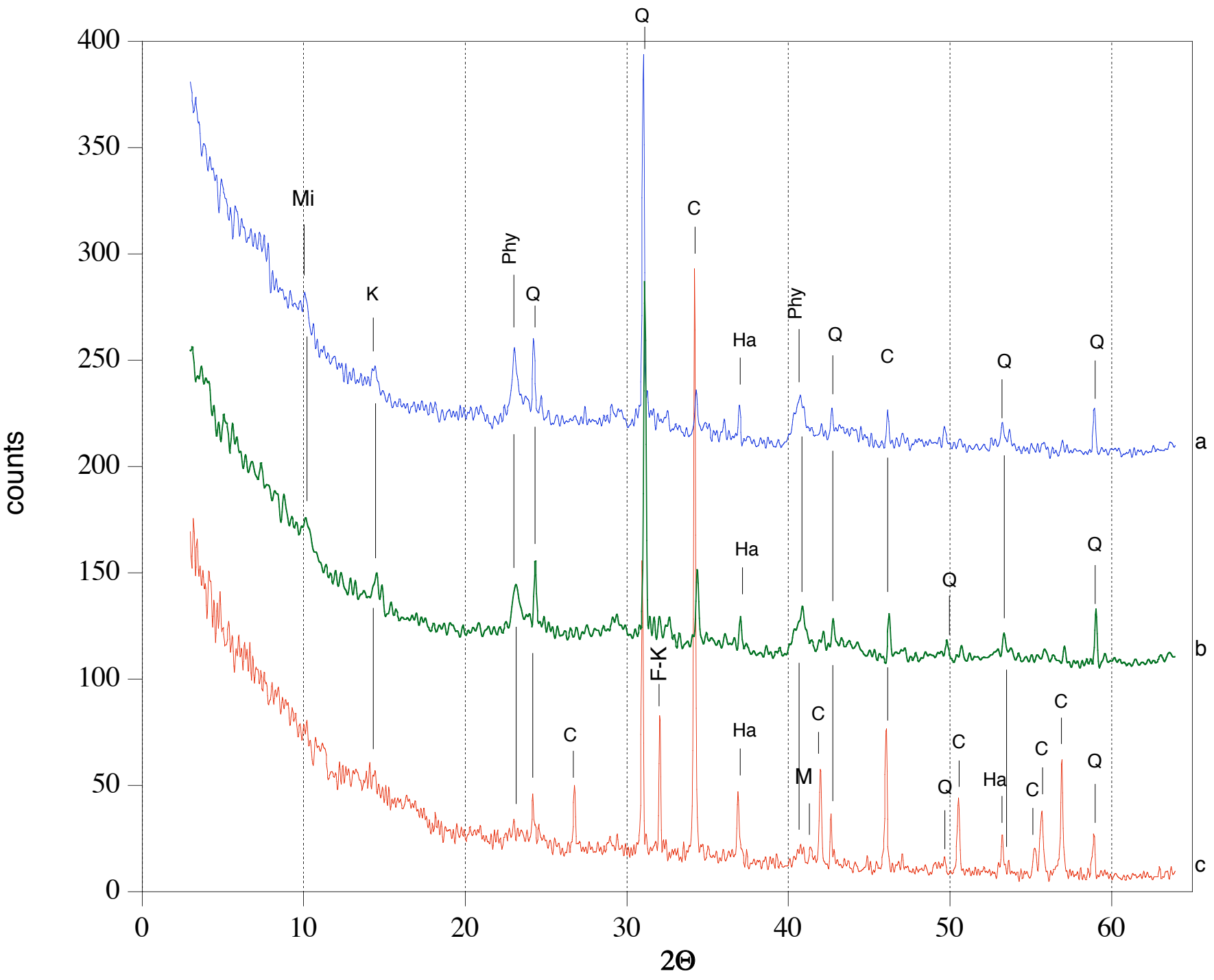

Figure 10 


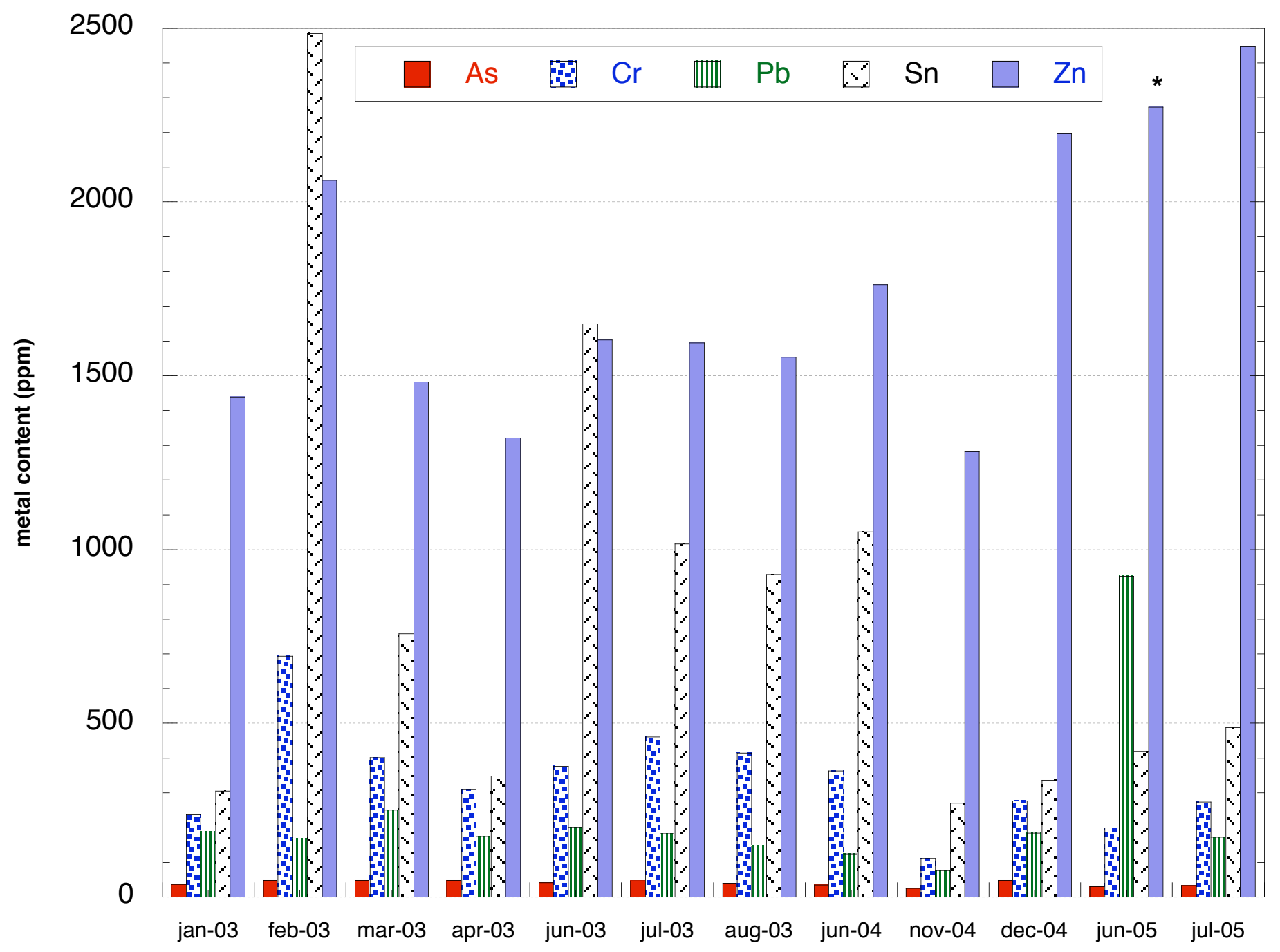

Figure 11 

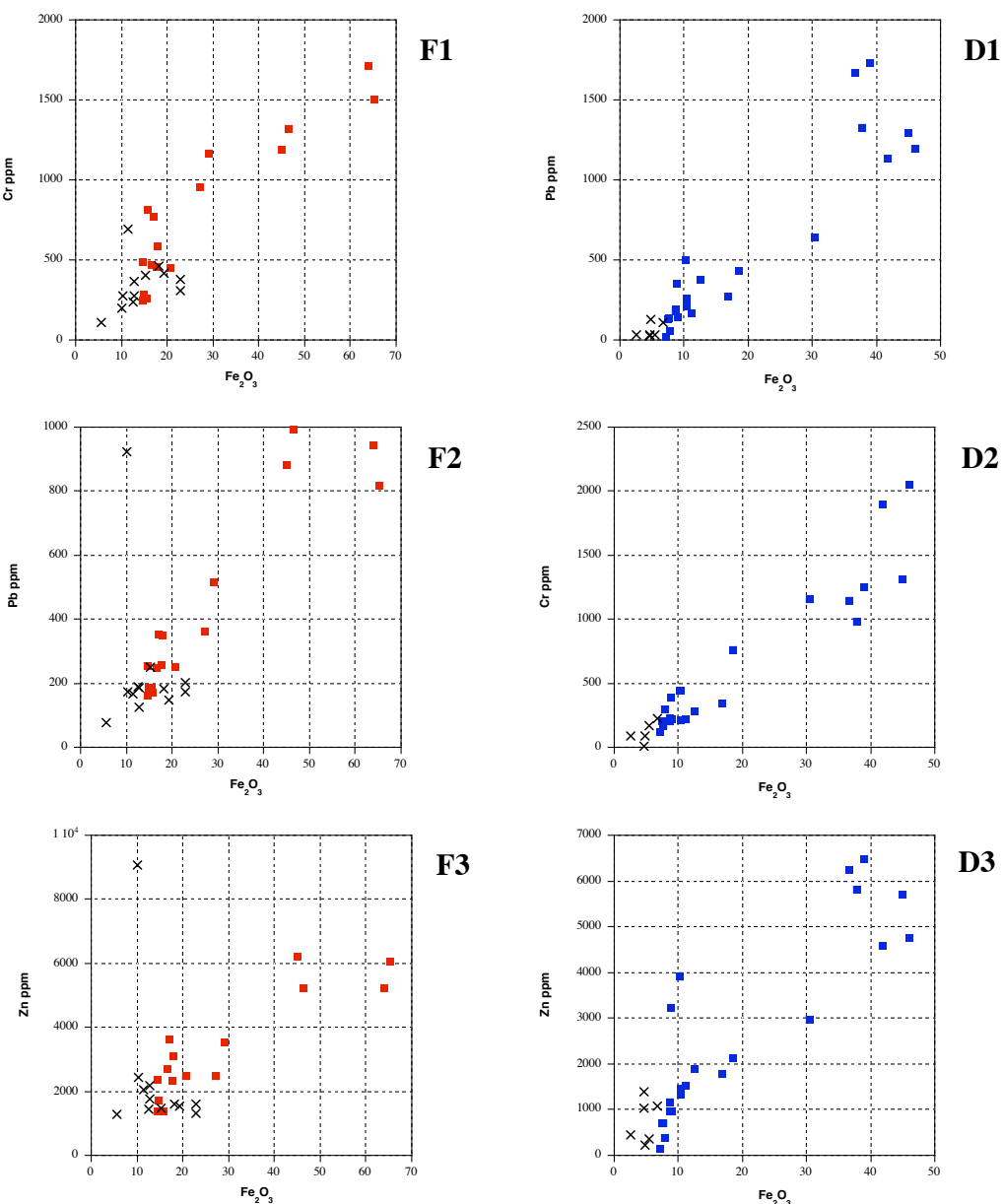

F3
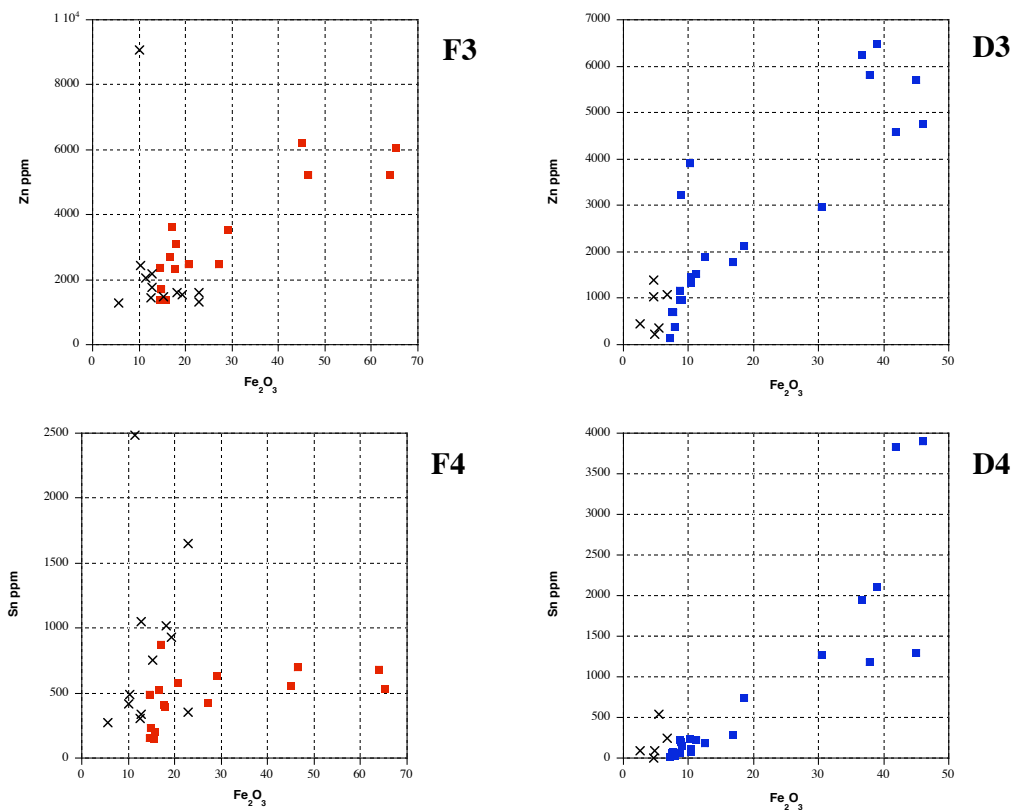

F4

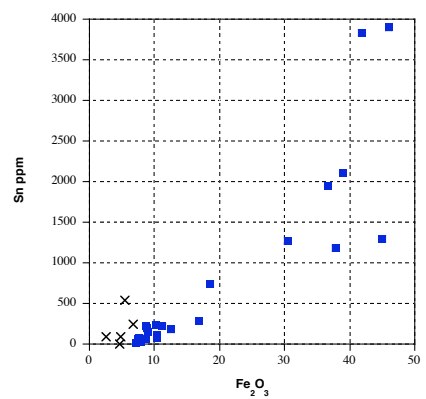

D4

figure 12 